\title{
Luminescence chronology of cave sediments at the Atapuerca paleoanthropological site, Spain
}

\author{
G.W. Berger ${ }^{\mathrm{a}, *}$, A. Pérez-González ${ }^{\mathrm{b}}$, E. Carbonell ${ }^{\mathrm{c}}$, J.L. Arsuaga ${ }^{\mathrm{d}}$, \\ J.-M. Bermúdez de Castro ${ }^{\text {b }}$, T.-L. Ku ${ }^{\text {e }}$ \\ ${ }^{a}$ Desert Research Institute, 2215 Raggio Parkway, Reno, NV 89512, USA \\ ${ }^{\mathrm{b}}$ Centro Nacional de Investigación sobre Evolución Humana, CENIEH, Burgos, Spain \\ 'Área de Prehistoria, Universitat Rovira I Virgili, Unidad Asociada al CSIC, 43005 Tarragona, Spain \\ ${ }^{d}$ Centro Mixto UCM-1SCIII de Evolución y Comportamientos Humanos, Sinesio Delgado 4-6, 28029 Madrid, Spain \\ ${ }^{e}$ Department of Earth Sciences, University of Southern Califomia, Los Angeles, CA 90089, USA
}

Keywords:

Atapuerca

Dating

Hominin

Luminescence

Karstic caves

Spain

\begin{abstract}
A B S T R A C T
Ascertaining the timing of the peopling of Europe, after the first out-of-Africa demographic expansion at the end of the Pliocene, is of great interest to paleoanthropologists. One of the earliest direct evidences for fossil hominins in western Europe comes from an infilled karstic cave site called Gran Dolina at Atapuerca, in a stratum $\sim 1.5 \mathrm{~m}$ below the Brunhes-Matuyama (B-M) geomagnetic boundary (780 ka) within lithostratigraphic unit TD6. However, most of the meters of fossil- and tool-bearing strata at Gran Dolina have been difficult to date. Therefore, we applied both thermoluminescence (TL) and infraredstimulated-luminescence (IRSL) multi-aliquot dating methods to fine-silt fractions from sediment samples within Gran Dolina and the nearby Galería cave site. We also applied these methods to samples from the present-day surface soils on the surrounding limestone hill slopes to test the luminescenceclock-zeroing-by-daylight assumption. Within the uppermost $4 \mathrm{~m}$ of the cave deposits at Gran Dolina, TL and paired TL and IRSL ages range stratigraphically from $198 \pm 19 \mathrm{ka}$ to $244 \pm 26 \mathrm{ka}$. Throughout Gran Dolina, all luminescence results are stratigraphically self-consistent and, excepting results from two stratigraphic units, are consistent with prior ESR-U-series ages from progressively deeper strata. Thermoluminescence ages culminate at $960 \pm 120$ ka approximately $1 \mathrm{~m}$ below the $780 \mathrm{ka}$ B-M boundary. At Galería, with one exception, TL and IRSL ages range stratigraphically downward from $185 \pm 26 \mathrm{ka}$ to $503 \pm 95 \mathrm{ka}$ at the base of the lowermost surface-inwash facies. These results indicate that TL and (sometimes) IRSL are useful dating tools for karstic inwash sediments older than ca. $100 \mathrm{ka}$, and that a more accurate chronostratigraphic correlation is now possible among the main Atapuerca sites (Gran Dolina, Galería, Sima de los Huesos). Furthermore, the oldest TL age of ca. 960 ka from Gran Dolina, consistent with biostratigraphic and paleomagnetic evidence, implies a probable numeric age of $900-950 \mathrm{ka}$ for the oldest hominin remains ( $\sim 0.8 \mathrm{~m}$ below the TL sample). This age window suggests a correspondence to Marine Isotope Stage (MIS) 25, a relatively warm and humid interglaciation.
\end{abstract}

\section{Introduction}

The Atapuerca paleoanthropological sites, near Burgos in northern Spain, contain the world's most extraordinary accumulation of Pleistocene fossil humans and related stone artifacts (e.g., Arsuaga et al., 1993, 1999a,b; Carbonell et al., 1995, 1999; Bermúdez de Castro et al., 1997, 1999, 2004; Parés et al., 2006). In particular, the infilled karstic cave site called Gran Dolina (TD) has yielded the heretofore oldest direct evidence of hominins in Europe west of the
Republic of Georgia. More than a hundred hominin remains have been recovered so far from the so-called Aurora stratum within lithostratigraphic unit TD6, 1.5 m below the Brunhes-Matuyama (B-M) geomagnetic boundary (Parés and Pérez-González, 1999).

These remarkable finds have generated discussion and controversy about the origin of modern Europeans (e.g., Delson, 1997; Ambrose, 2001; Manzi, 2004; Parfitt et al., 2005; Roebroeks, 2005; Dennell and Roebroeks, 2005; Carbonell and Rodríguez, 2006). Speculation about the possible migration routes of human ancestors into Europe (e.g., Aguirre and Carbonell, 2001; Balter, 2001; Dennell, 2003) has recently been reinterpreted by Dennell and Roebroeks (2005), who argued that the extant "out-of-Africa-1" (e.g., Tattersall, 1997) hypothesis should be replaced by a scenario in 
which early hominins occupied Asiatic grasslands by $3.0-3.5 \mathrm{Ma}$, followed by "two-way traffic," which would be responsible for the presence of the genus Homo across central-southern Asia by ca. $1.8 \mathrm{Ma}$. In this context, migratory origins (Ambrose, 2001; Balter, 2001; Cann, 2001; Culotta et al., 2001; Gibbons, 2001a,b; Marshall, 2001a,b; Pennisi, 2001; Stumpf and Goldstein, 2001) of the fossil humans in Spain, now known to have been present at least as early as the time window 0.78-1.80 Ma (Parés et al., 2006; Scott et al., 2007), take on new significance. For example, new questions can be considered. If hominins were present in Spain as easly as $1.8 \mathrm{Ma}$, what was their relationship, if any, to hominins apparently present at about that time across central-southern Asia? If hominins were present at Gran Dolina close to $1 \mathrm{Ma}$, as our data imply, what was their relationship, if any, to those hominins present in the same area (Pares et al., 2006) at earlier times (e.g., 1.2-1.8 Ma)?

The most important sites at Atapuerca are Gran Dolina (site TD) and Galería (TG) in an abandoned railway cut or trench (La Trinchera;, as well as Sima de los Huesos (SH: "Pit of the Bones"; approximately $400 \mathrm{~m}$ away (Fig. 1). English-language histories of the exploration and discovery of these remarkable sites have been presented by Aguirre et al. (1990), Arsuaga et al. (1997a,b), Balter (2001), and Carbonell et al. (1999), with popular accounts given by Arsuaga (2003) and Kunzig (1997). The increasing importance of a third site within the railway trench, Sima del Elefante (site TE; Fig. 1), is recognized (Rosas et al., 2004; Parés et al., 2006). There, paleomagnetic and biostratigraphic results have placed the age of lithic tools (hence the presence of hominins) in the early Pleistocene (0.78-1.77 Ma).

Daring the remains from La Trinchera and their enclosing sediments has been unusually difficult. The main reason is that the sediments are infill deposits in Pleistocene caverns within a karstic terrain of the Sierra de Atapuerca, and thus contain no heated minerals amenable to $\mathrm{Ar}-\mathrm{Ar}$ and fission-track dating. However, dating authigenic minerals by Ar-Ar methods (e.g., Dickin, 1997; McDougall and Harrison, 1999; Hagen et al., 2001) may be possible, and daring unheated quartz grains by cosmogenic-nuclide methods (e.g. Dickin, 1997; Gosse and Phillips, 2001; Anthony and Granger, 2007) is possible (Carbonell et al., 2008). Several of the deposits are within the 50-400-kyr age range of conventional $U$-Th-series dating (e.g., Dickin, 1997; Ku, 2000), and within the somewhat longer age range of electron-spin-resonance (ESR) dating of tooth enamel (e.g., Rink, 1997). The relative-dating tool of geomagnetic-reversal stratigraphy (e.g., Verosub, 2000) has been applied at Atapuerca. Thus, the most reliable and critical datum for assigning an age to the oldest hominin remains at Gran Dolina has been the determination of the B-M geomagnetic-reversal boundary (age $781 \pm 3 \mathrm{ka}$; Horng et al., 2002) in upper stracigraphic unit TD7 (Parés and Pérez-González, 1999), $\sim 1.5 \mathrm{~m}$ above the homininbearing horizon in unit TD6.

Because of the importance of these sites and of the limited application of other dating techniques, we have applied those multi-aliquot luminescence sediment-dating methods (e.g. Aitken, 1985,1998 ) that were available to us at the time of commencement of this project (1998). We thought that the more recently developed methods of single-aliquor and single-yrain photon-stimulatedluminescence dating (Aicken، 1998) (also termed optical or photonic dating) of quartz (e.g., Murray and Olley, 2002; Berger et al., 2003; Bøtter-Jensen et al., 2003) were unlikely to be useful here because all our stracigraphically importanc samples were thought to be greater than ca. $100 \mathrm{kyr}$ in age. For sediments having typical concentrations of $U, T h$, and $K$, precise single-aliculot-c|uart $\angle$ dating is usually limited to the last ca. $150 \mathrm{kyr}$ (Murray and olley, 2002). However, Rhodes et al. (2006) reported that one calcareous sandysilt sample somewhat below the B-M geomagnetic-reversal boundary, at an archeological site near Casablanca in Morocco, yielded an opcical age estimate of $990 \pm 210 \mathrm{ka}$, while some

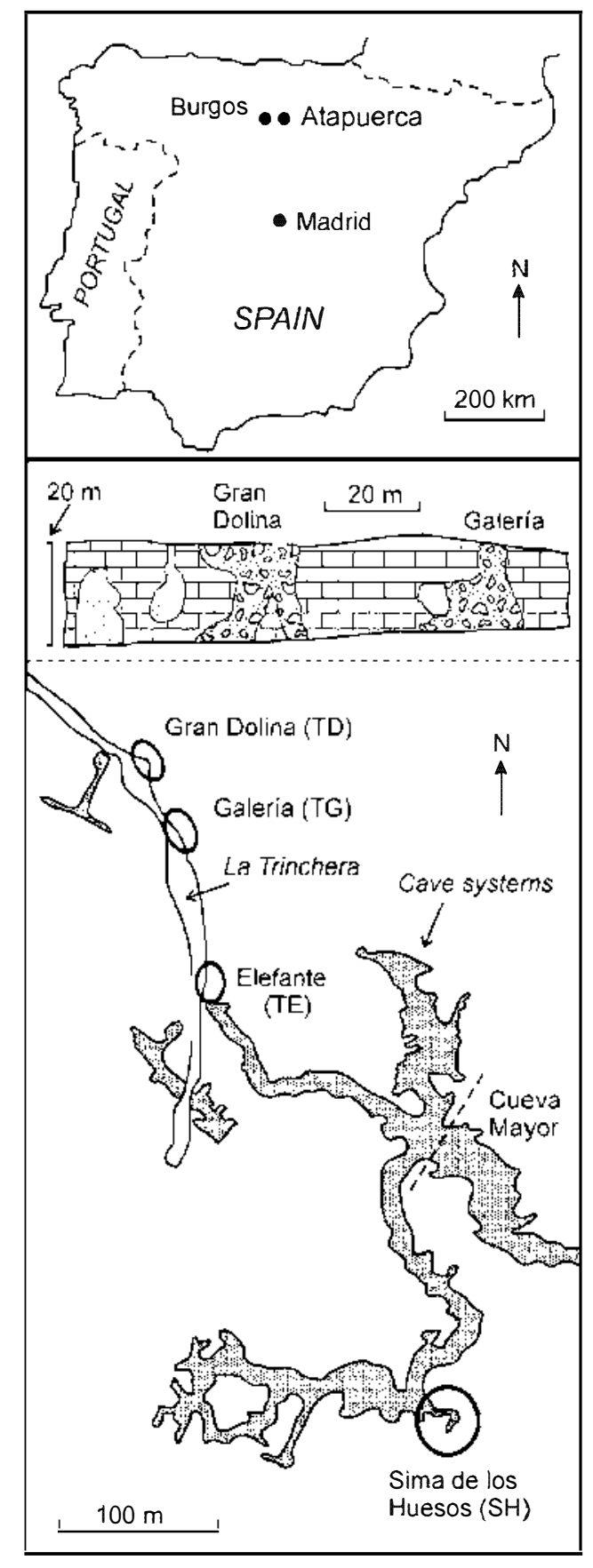

Fig. 1. Location of the Atapuerca sites (top), schematic profile of the Gran Dolina and Galeria cave deposits (center), and a plan view of the sites and cave system (lower). The profile view shows mixed sediments infilling passages within the limestone bedrock, with an unfilled cavity at the left side of Galeria. In the plan view, the subsurface caves are shaded.

samples stracigraphically above the B-M boundary gave optical ages on quartz of $\mathrm{ca}$. 400-500 ka. Importantly, the dose rates in all their sediments were unusually low, 0.4-0.8 Gy/ka, thus permitting quartz dating well heyond ca. $150 \mathrm{ka}$. The recent demonstration of single-aliquor-quartz optical ages up to ca. $500 \mathrm{ka}$ for a karstic cave setting in Australia (Prideaux et al., 2007a) similarly depends on low dose rates in the enclosing sediments $(\sim 0.6 \mathrm{~Gy} / \mathrm{ka})$.

Gran Dolina and Galeria are the main subjects of this paper because, of the three sites available to us in the late 1990s (TD, TG, SH), only TD and TG have sediments that might meet the main requirement of luminescence sediment dating that mineral grains be exposed to daylight not too long before burial. 


\section{Geological setting and samples}

The geological setting of the endokarst and the nature of the deposits have been described by Carbonell et al. (1999), Parés and Pérez-González (1999), and Pérez-González et al. (1999, 2001). From the viewpoint of luminescence dating, there are three important traits in the setting and the deposits: (1) the bedrock is Mesozoic limestone, and the karstic structure was developed no later than the early Pleistocene (e.g., Pérez-González et al., 1999, 2001; Parés et al., 2006); (2) upslope of the filled TD and TG cave entrances, the bedrock surface is covered by patches of thin $(10-50 \mathrm{~cm}$ thick) terra-rossa soil (e.g., Jenny, 1980; Martini and Chesworth, 1992); (3) the cave passages are filled with both a reddish matrix (exterior or "entrada" facies deposits) and an underlying (basal) tan-beige matrix ("interior" facies) (PérezGonzález et al., 1999, 2001).

The 18-m-thick exposure of interior and exterior facies deposits at TD is divided into 11 stratigraphic levels (Fig. 2, left): TD1-TD11, bottom to top (e.g., Parés and Pérez-González, 1995, 1999). The $\sim 16$-m exposure at TG is divided into six stratigraphic levels (Fig. 2, right) (G1-G6, bottom to top; Pérez-González et al., 1995, 1999, 2001), with G1 being an interior facies deposit, and G2 and G3 containing fossils and evidence of hominin occupation.

A limestone character of the bedrock ensures that any fragments of bedrock that are dissolved or finely comminuted will contribute a very small or negligible proportion of feldspars and quartz to the sediment matrix. Quartz and feldspar grains carry most of the luminescence signal in typical sediments. Our objective was to date sediment greater than $100 \mathrm{ka}$ in age. Although the exterior facies deposits have $12-50 \%$ quartz (Pérez-González et al., 1995, 1999), and although quartz provides a highly stable luminescence signal (e.g., Aitken, 1985, 1998), the upper age limit of quartz in normal sediments is ca. $200 \mathrm{ka}$ or less. Alternatively, feldspar concentration in these cave deposits was estimated to be only $\sim 5 \%$ (Pérez-González et al., 1995, 1999). However, because feldspar thermoluminescence $(\mathrm{TL})$ is $\sim 20-50$
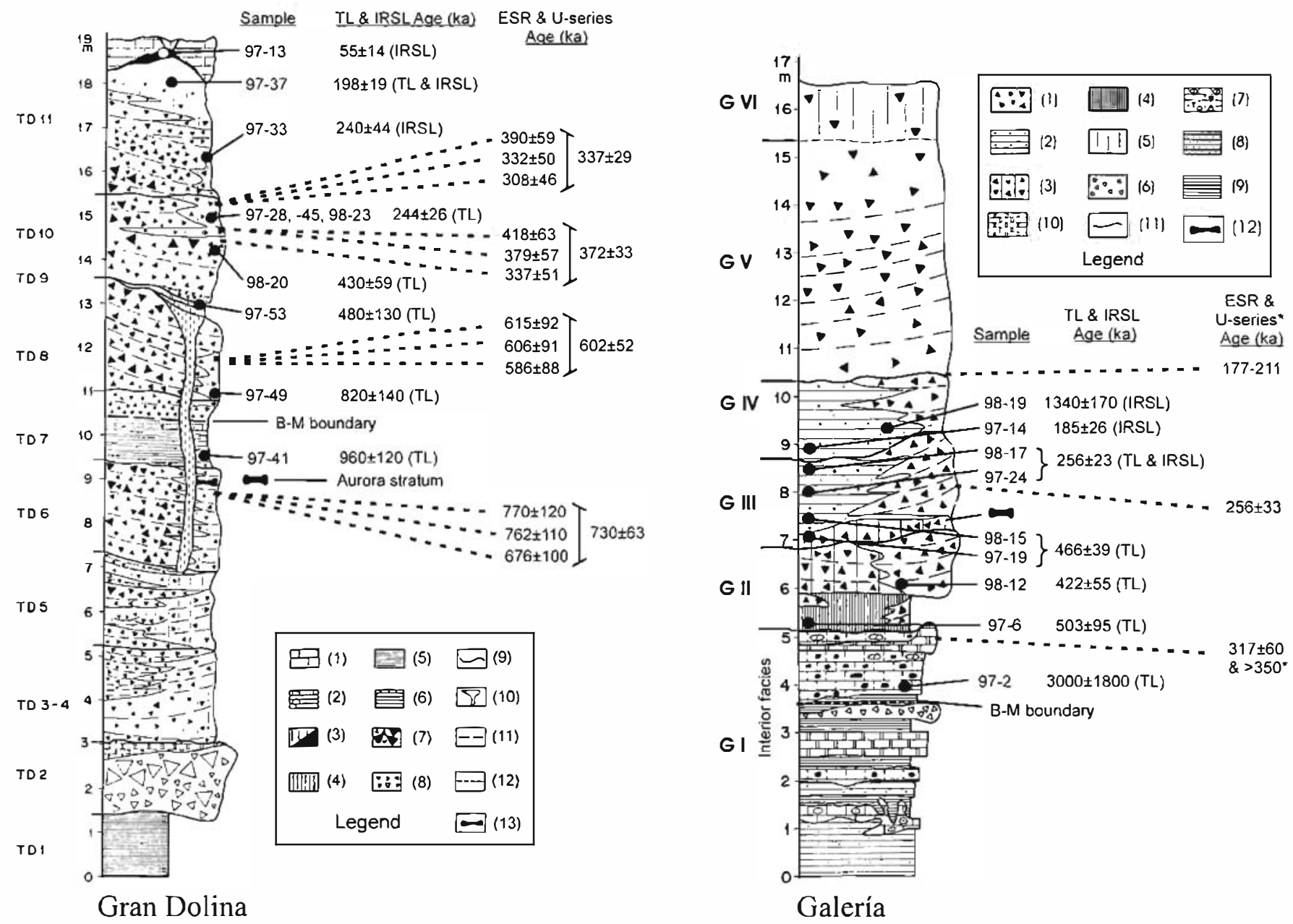

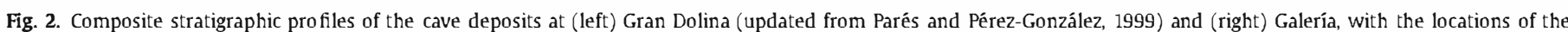

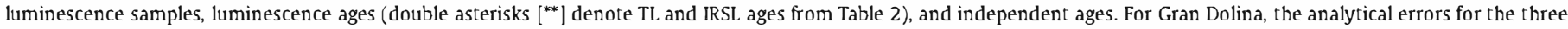

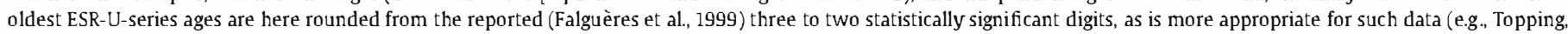



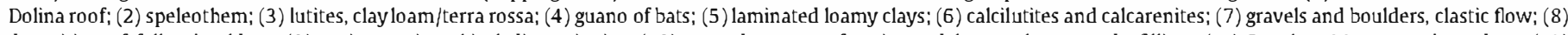

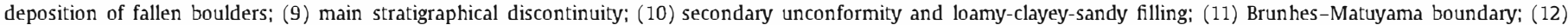

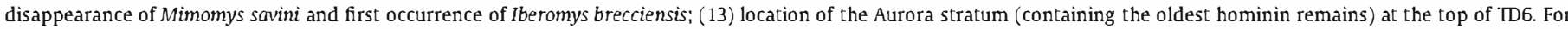



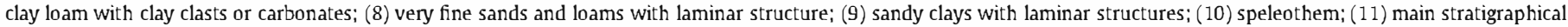

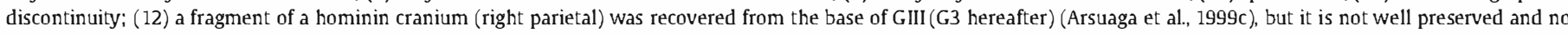
species assignment has been made. 
times brighter than an equivalent amount of quartz (Wintle, 1982; Berger, 1984; Aitken, 1985), we expected TL signals from polymineral, fine-silt-sized samples to be dominated by feldspar signals. These cave deposits are also suitable for multi-aliquot $\mathrm{TL}$ or infrared-stimulated-luminescence (IRSL) dating because there is little likelihood of significant contamination by light-shielded quartz or feldspar grains that could be released into the matrix by dissolution of local limestone, either in situ or during laboratory preparation of samples containing small clasts of limestone. The concentration of feldspar and quartz within the local limestone is a factor of at least 40-500 less than in the cave sediments (Aleixandre and Pérez-González, 1999).

The strikingly reddish coloration of the karstic infill matrix overlying the lowest cave units (which are tan-colored) attests to the origin of the infill matrix as downslope wash from the past terra-rossa surface soil (Pérez-González et al., 1995, 1999). In this context, the preservation of a remnant terra rossa on the upslope bedrock surface provides a modern analogue to the likely past upslope material that periodically washed downslope into the cave entrances, mixing with small and large limestone breccia, to gradually fill the TD and TG caves.

Most of the upslope sediment that washed into the caves was likely transported during energetic events. Because mass transport was the main mechanism in the trinchera (Pérez-González et al. 1999), it is unlikely than many or any of the fine-silt-sized mineral grains would have been exposed to sufficient daylight to significantly reset the luminescence clock during transport. In general depositional settings, floodwaters and episodic transport of slurries typically shield most grains from light. There are many published examples illustrating gross age overestimation when such alluvial sediments are dated by multi-aliquot TL and IRSL. Therefore, before we could fully interpret TL and IRSL ages from the matrix of the cave deposits, we needed to establish that upslope sediment likely had small residual luminescence ages before being transported into the caves. For this reason we collected samples from the present thin sediments on the limestone bedrock upslope of the caves.

Our hypothesis was that the reddish matrix of the exterior facies deposits in TD and TG contains a significant fraction of eolian silt grains. Continually added to surface sediments (see online Supplementary material), such grains would carry a small relict luminescence age. Because the youngest deposits in the caves were thought to exceed ca. $100 \mathrm{ka}$, and since a typical analytical uncertainty in luminescence age estimates is $\sim 10 \%$, we require any relict or inherited age from the inwash sediment to be less than $10 \mathrm{kyr}$ (but could be larger for older samples) for samples older than $100 \mathrm{ka}$.

Within the various cave deposits, we collected blocks of matrix during daylight, and opaque bags of friable matrix sample during diurnal darkness, at stratigraphic locations shown in Fig. 2. Sample collection occurred in the summers of 1997 and 1998. All outer portions ( $\sim-10 \mathrm{~mm}$ ) of daylight-exposed blocks were removed in the controlled-lighting luminescence-dating laboratory at the Desert Research Institute (DRI) in Reno, NV, USA. The collected samples are described in Supplementary Table S1.

\section{Prior age estimates at Atapuerca}

\section{Gran Dolina}

The presence of remains of the micromammal Mimomys savini (a water vole) only below the upper $40-50 \mathrm{~cm}$ of TD8 constrains this and lower levels to ages older than ca. 500 ka (e.g., Carbonell et al., 1995, 1999; Laplana and Cuenca-Bescós, 1997). The first reliable numeric age estimate for the TD deposits was provided by Parés and Pérez-González (1995, 1999), who located the B-M boundary within upper TD7, thus constraining the hominin fossils in the underlying TD6 to be older than $780 \mathrm{ka}$, and making them the oldest European hominin fossils (e.g., Carbonell et al., 1995; Bermúdez de Castro et al., 1997). Below unit TD7, and to the lowest unit TD1, only reversed paleomagnetic polarity was observed, with a suggestion (a single-sample data point) of an excursion or reversal in unit TD1. However, between TD7 and TD1, the paleomagnetic samples were collected at widely spaced intervals. If the excursion in TD1 represents the Jaramillo polarity-normal interval, then all deposits between TD7 and TD1 represent the time interval 780-990 ka (Horng et al., 2002), including the hominin remains in TD6. Recently, the strata containing lithic artifacts at Elefante (site TE; Fig. 1) have been determined to be older than ca. $780 \mathrm{ka}$, possibly older than $1.07 \mathrm{Ma}$, based on paleomagnetic analyses (Parés et al., 2006).

Above horizon TD7, useful material for numeric dating has been difficult to obtain. Although the deposits at Gran Dolina (and Galería) contain carbonate that is in principle suitable for U-series dating, the open-system behavior of the isotopes has precluded stratigraphically systematic results (Bischoff, pers. comm.). We note, however, that two samples of vein fill within TD11 produced reasonable U-series age estimates of $240 \pm 25 \mathrm{ka}$ (average) (Bischoff, pers. comm.).

Combined ESR-U-series dating of ungulate tooth enamel from the Gran Dolina site (Falguères et al., 1999, 2001) has produced the most systematic results so far for both Gran Dolina and Galería. Age estimates range from $300-400 \mathrm{ka}$ in the upper part of TD10 to ca. $600 \mathrm{ka}$ in TD8, and ca. $750 \mathrm{ka}$ in TD6, below the B-M boundary (Fig. 2, left). Note that Falguères et al. $(1999,2001)$ placed three of their samples well within unit TD11, but the correct stratigraphic placement apparently is near the top of the underlying TD10 (Fig. 8 in Pérez-González et al., 2001). Similarly, for the underlying TD10 samples of Falguères et al. (1999, 2001), Pérez-González et al. (2001) provide a clearer stratigraphic location.

At nearby Sima de los Huesos (Fig. 1), U-series dating of carbonate (in situ speleothem) also was successful, producing a lower-limiting age estimate of $\mathrm{ca}$. $350 \mathrm{ka}$, with a stratigraphically extrapolated probable age of 400-500 ka (Bischoff et al., 2003) for underlying human bones. That age estimate has been revised upward to a minimum of ca. $530 \mathrm{ka}$ (Bischoff et al., 2007) by use of higher-precision U-series dating.

\section{Galeria}

Very few dating results have been reported for Galería. The B-M boundary has been placed in the upper part of unit G1, $3.5 \mathrm{~m}$ above its base (Pérez-González et al., 1999, 2001). At the boundary between G1 and the overlying G2, a speleothem has yielded an ESR age of $317 \pm 60 \mathrm{ka}$ and a limiting U-series age estimate of greater than 350 ka (reviewed by Aguirre, 1994; Pérez-González et al., 2001). Within the lower part of the overlying G3 unit, speleothem has given an ESR age estimate of $256 \pm 33 \mathrm{ka}$ (Aguirre, 1994), while carbonate pieces and speleothem in the base of the overlying lower G5 unit have yielded ESR age estimates of $177 \pm 23 \mathrm{ka}$ and $211 \pm 32$ ka (summarized by Aguirre, 1994; Pérez-González et al., 1999, 2001; Falguères et al., 2001) (Fig. 2, right).

Because the sediments at both Gran Dolina and Galería are older than ca. $100 \mathrm{ka}$ and are directly non-eolian (not wind borne), they presumably would be difficult to date with luminescence sediment-dating methods. Nevertheless, we have applied luminescence methods to some of these deposits, motivated by the reported success of Berger (1994, 1995) and Berger et al. (1992) in attaining accurate TL ages from fine-silt-sized feldspars up to ca. $800 \mathrm{ka}$, and accurate IRSL ages up to ca. $400 \mathrm{ka}$ (Berger, 2001) for several independently dated eolian fine-silt deposits (loess) from New Zealand and Alaska. 
We reported early results in abstracts (Berger and PérezGonzález, 2000; Berger et al., 2005). Since then, only a few other attempts have been reported to date karstic infill sediments by luminescence methods (Morwood et al., 2004; Turney et al., 2001; Prideaux et al., 2007a,b). Morwood et al. (2004) applied IRSL and red-TL procedures to cave infill sediments to obtain age estimates of $\mathrm{ca} .14 \mathrm{ka}$ and $35 \mathrm{ka}$ stratigraphically bracketing a hominin skeleton. These results were obtained from slopewash sediments, but it was not reported whether the luminescence in the sediment grains was zeroed before deposition in the cave. Thus, the ca. $35 \mathrm{ka}$ age estimate could greatly exceed the burial age. Stratigraphically comparable radiocarbon ages average ca. $18 \mathrm{ka}$. Turney et al. (2001) reported OSL (optically stimulated luminescence, or optical) ages in the range $40-50 \mathrm{ka}$ for quartz grains from slopewashed sediments enclosing human artifacts. Here, the sediments originated mainly from eolian dunes outside the cave, thus ensuring adequate zeroing of the luminescence clock before grain burial in the cave. Similarly, Prideaux et al. (2007a) reported OSL ages for quartz from quartz-rich horizons in Cathedral Cave ranging from ca. $200 \mathrm{ka}$ to $\mathrm{ca}$. $500 \mathrm{ka}$. Although they did not comment on the likely origin of this quartz, they apparently presumed that the quartz was washed into the cave from originally eolian deposits. Prideaux et al. (2007b) reported OSL age estimates for cave-infill quartz grains ranging from ca. $30 \mathrm{ka}$ to ca. $230 \mathrm{ka}$, but no mention was made of the origin of these grains. Because these grains were inwashed during floodwater episodes, it is unclear how well the luminescence clock might have been zeroed before grain burial. The single-aliquot results of Prideaux et al. (2007b) indicate poor clock-zeroing for most of the infill sediment.

Several reports of luminescence dating of other rock-shelter and cave-infill unheated sediments have been made, for which the cave bedrock is sandstone, micaceous schist, other noncarbonate rock, or calcarenite, and the deposits are younger than ca. $80 \mathrm{ka}$. In these other applications (Abeyratne et al., 1997; Feathers, 1997; Smith et al., 1997; Jacobs et al., 2003a,b), fine-sand-sized quartz has been employed, rather than the polymineral fine-silt fraction that we used. In most of these applications (Abeyratne et al., 1997; Feathers, 1997; Smith et al., 1997), the authors assumed their samples were entirely or dominantly eolian, and some conducted tests to check this assumption. Each group discussed the possibility that quartz from comminuted fragments of the cave walls and roof were incorporated into their samples. Feathers (1997) also allowed that local colluvium could have been admixed with eolian grains. These groups employed multi-aliquot procedures or early versions of many-grain single-aliquot procedures. On the other hand, Jacobs et al. (2003a,b) applied the more recent manygrain-single-aliquot and the single-grain procedures to sand-sized quartz grains that are clearly eolian and deposited within a calcarenite cave.

In all such applications, where the bedrock contains a significant fraction of quartz, and where the infill deposits are younger than $100-150 \mathrm{ka}$, the most accurate luminescence-dating approach is probably the single-grain-quartz approach, pioneered in such settings by Roberts et al. (1999) and advanced by Jacobs et al. (2003b). This approach enables, as can the few-grain-singlealiquot method (e.g., Prideaux et al., 2007b), statistical discrimination between eolian or last-zeroed quartz grains and older grains representing fragments of wall rock or colluvium containing significant relict luminescence signals at burial time. Equipment for the application of this modern approach was not available to us during this project, nor did we judge that the method would likely have been useful because of the expected antiquity of our cave sediments.
An age estimate equals paleodose divided by dose rate, which equals $D_{E} / D_{R}$, where $D_{E}$ is derived from luminescence measurements. To derive $D_{E}$ values, we used the total-bleach (TB) extrapolation-dose-response procedure for both TL and IRSL (Berger and Péwé, 2001; Berger, 2003), and also the "Australian slide" regenerative-dose-response procedure (Prescott et al., 1993) for both TL and IRSL. However, the ten samples analyzed with the slide procedure consistently yielded underestimates in $D_{E}$ values compared to the TB extrapolation-dose-response procedure for most samples and its use was discontinued, with no results being reported here.

The TL and IRSL procedures we chose require adequate concentrations of K-feldspars in the fine-silt size fractions. PérezGonzález et al. $(1995,1999)$ reported general estimates of feldspar concentrations within the cave deposits. To obtain localized estimates of feldspar concentrations and the ratios of compositional groups of feldspars-as well as quartz-feldspar ratios-from the identical $\sim 0.5-\mathrm{mg}$ aliquots used for luminescence dating, we conducted a few point-count SEM-EDX probe analyses.

To calculate dose rates, we used the laboratory procedures employed by Berger and Péwé (2001): commercial atomic absorption spectroscopy (AAS) for $\mathrm{K}_{2} \mathrm{O}$, and thick-source-alpha-particle-counting (TSAC; Huntley and Wintle, 1981) for $U$ and Th count rates. Two supplementary procedures were used to check the AAS and TSAC results. In 1997, we employed a $2 \pi$-geometry, 4-channel portable, $\mathrm{NaI}(\mathrm{Tl})$-crystal gamma spectrometer (e.g., Aitken, 1985) at some horizons. In 1998, several $\sim 1-\mathrm{kg}$ samples were collected specifically for intrinsic-Ge high-resolution gamma spectrometry (HRGS) at the University of Southern California (USC) (e.g., Luo et al., 2000).

Further details of the above methods pertaining to this project are provided in the online Supplementary material.

\section{Results}

The results of SEM-EDX analyses for mineral-concentration estimates are listed in Table 1. The images for sample ATP97-49 (Fig. 3) are representative of the selected samples. Most of the feldspar grains appear to be K-rich, with a small to negligible fraction in this example being Ca-rich (therefore dark or only slightly visible in Fig. 3). No albite (Na-rich feldspar) grains were identified. No zircon grains were detected. Zircon can produce problematic luminescence (e.g., Aitken, 1998). Overall, these results indicate that we have a usefully large fraction of K-feldspars

Table 1

Mineral percentages from SEM-EDX analyses of 4-11- $\mu$ m-diameter grains ${ }^{a}$

\begin{tabular}{|c|c|c|c|c|c|c|c|}
\hline Sample (ATP) & $\begin{array}{l}\text { Total } \\
\text { points }\end{array}$ & Quartz & K-Fs & $\begin{array}{l}\text { Hybrid } \\
\text { Fs }\end{array}$ & Plagioclase & Lithics & Other $^{c}$ \\
\hline \multicolumn{8}{|l|}{ Galería } \\
\hline $98-19$ & 200 & 27.5 & 15.0 & 6.5 & 0 & 5.5 & 45.5 \\
\hline $97-24$ & 175 & 28.6 & 1.7 & 3.4 & 0 & 4.6 & 61.7 \\
\hline $98-12$ & 175 & 44.0 & 13.1 & 2.3 & 1.1 & 6.9 & 32.6 \\
\hline $97-6$ & 175 & 13.7 & 6.9 & 4.6 & 0 & 8.6 & 66.3 \\
\hline \multicolumn{8}{|l|}{0.5} \\
\hline \multicolumn{8}{|l|}{ Gran Dolina } \\
\hline $97-33$ & 175 & 21.1 & 10.3 & 10.3 & 0 & 5.1 & 53.1 \\
\hline $97-28$ & 175 & 36.6 & 10.9 & 10.9 & 0 & 8.0 & 33.7 \\
\hline $98-20$ & 175 & 25.7 & 17.7 & 0 & 0 & 13.1 & 43.4 \\
\hline $97-49$ & 175 & 39.4 & 7.4 & 6.3 & 0 & 2.9 & 44.0 \\
\hline $97-41$ & 200 & 30.5 & 14.0 & 0 & 0 & 5.5 & 50.0 \\
\hline
\end{tabular}

${ }^{a}$ Samples were treated previously in $\mathrm{HCl}$ acid to dissolve carbonates and in $\mathrm{H}_{2} \mathrm{O}_{2}$ to destroy organic material.

b This represents composite grains of feldspar (e.g., partially altered feldspars).

c Generally, this category represents, in order: muscovite (or other Al-rich K-silicates) and minor-Fe clay minerals, with minor amounts of biotite and amphibole. 

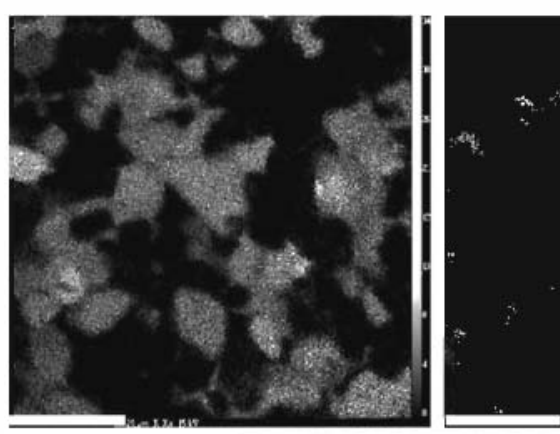

紫

$\mathrm{K}$

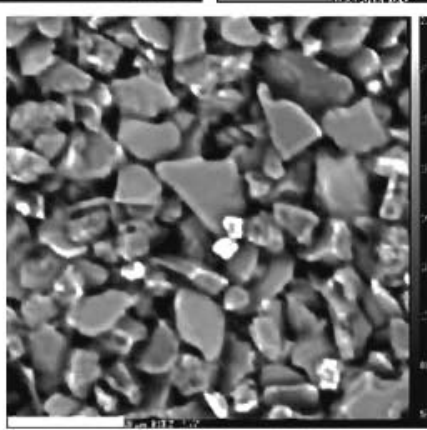

$\mathrm{Na}$

$\mathrm{Fe}$

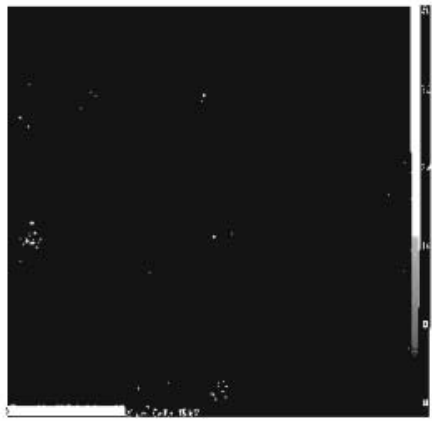

Fig. 3. Back-scatter-electron (BSE) SEM image (center) for siliciclastic grains of 4 $11 . . \mathrm{m}$ diameters in an aliquot of sample ATP97-49 previously used for TL. Also shown are SEM-EDX element-map images of the same field of view tuned to detect $\mathrm{K}, \mathrm{Na}, \mathrm{Fe}$ and $\mathrm{Ca}$. Dark areas indicate grains having little or none of the target elements. White scale bars (lower left) are $20 \mu \mathrm{m}$.

(7-18\%), little or no distinct plagioclase $(<1 \%)$, and $21-44 \%$ quartz in this fine-silt size range. Because the $\mathrm{TL}$ from feldspars is $20-50$ times brighter than that from quartz, the observed relative concentrations in Table 1 are favorable for TL dating. Moreover, as K-feldspars emit a generally stable signal at $\sim \mathbf{4 2 0} \mathrm{nm}$ wavelengths (Berger, 1994; Krbetschek et al., 1997), we performed all TL experiments using this emission.

The K-, U-, and Th-concentration values calculated from in situ 4-channel gamma field spectrometry ("field $\gamma$ " hereafter) and from laboratory high-resolution gamma spectrometry (HRGS hereafter) are listed in Supplementary Table S2. These are compared to the laboratory values from AAS and TSAC, employed for all TD and TG samples. The results indicate general agreement among the methods. Moreover, from the HRGS data, there appears to be no significant (for dose-rate calculations) radioactive-decay-series disequilibria (e.g., Olley et al., 1996, 1997). For this reason and others outlined in the Supplementary materials, we chose to calculate the dose rates using only the AAS and TSAC data.

The age estimates for the several surface-soil samples (Table 2) are in the range $0.3-6.0 \mathrm{ka}$, indicating that, if such material washed into the past caves, it would have carried a relict age of less than $10 \mathrm{ka}$. Thus, even without additional (uncertain) clock zeroing during downslope transport, these results suggest that inwash sediment forming the matrix of the cave deposits carries a statistically negligible systematic inherited-age offset for samples older than ca. $100 \mathrm{ka}$. Very likely, these low luminescence age estimates reflect the presence of modern and Holocene eolian grains (see online Supplementary material).

At Gran Dolina, two subadjacent samples of older terra rossa soil (samples 97-13; Supplementary Table S1 and Fig. 2) yielded a mean age of $55 \pm 14 \mathrm{ka}$, consistent with their stratigraphic position at the top lip of the cave passage. The luminescence results from these samples are consistent with an eolian origin of silt grains within forming surface soils (incipient and developed terra rossa) and subsequent downslope migration into the caves.

Our judgment of the accuracy of the TL and IRSL age estimates for cave-matrix sediment depends upon comparisons both within the luminescence data sets and between the data sets, as well as comparisons with independent relative (e.g., stratigraphic) and numeric (e.g., U-series, ESR, and ESR-U-series) age criteria.

With IRSL data, we looked for constancy of plateau $D_{E}$ values when we increased preheating temperatures above a certain level (e.g., above $140^{\circ} \mathrm{C}$; Ollerhead et al., 1994). An example of such constancy is shown in Fig. 4. We also looked for agreement between TL plateau $D_{E}$ values and those from IRSL (e.g., Fig. 4). For several samples in Table 2, we calculated weighted (by inverse variance) mean and concomitant standard error of the mean (e.g., Topping, 1962) when such concordance in $D_{E}$ values was observed. Particular anomalies in the TL $D_{\mathrm{E}}$-temperature plots (e.g., above $350^{\circ} \mathrm{C}$ in Fig. 4) are discussed in the online Supplementary material.

Comparison between TL and IRSL DE plots revealed that, at both Gran Dolina and Galería, IRSL $D_{E}$ plateau values began to diverge from TLvalues for samples older than ca. $250 \mathrm{ka}$, with the IRSL values ceasing to increase with stratigraphic age. Figure 5 (inset) provides an example of this age underestimation from IRSL data. Consequently, for all samples older than ca. $250 \mathrm{ka}$, we consider that only the TL results provide reasonable age estimates. Furthermore, as discussed in the online Supplementary material, we selected $\mathrm{TL}$ $\mathrm{D}_{\mathrm{E}}$ values only in the range below ca. $370^{\circ} \mathrm{C}$ in $\mathrm{D}_{\mathrm{E}}$-temperature plots. An example of this selection and the resultant age for the oldest sample analyzed is shown in Fig. 6 (inset). The imprecision of the resultant mean age arises from the relatively large uncertainties associated with the long dose-response extrapolations with such samples near the upper age limit of this dating procedure.

Based on the above reasoning, we plot in Fig. 2 only those age estimates in Table 2 denoted by two asterisks $\left({ }^{* *}\right)$. In addition, for Galería, we noticed that some of the age estimates from within a given stratigraphic unit are statistically identical (at $67 \%$ confidence). We therefore plot only the weighted mean ages for those results in Fig. 2 (right).

\section{Discussion}

\section{Stratigraphically anomalous TL ages}

A likely explanation for the anomalous 1.34-Myr IRSL result in the middle of unit G4 (Fig. 2, right, sample 98-19) is discussed in the online Supplementary material. More relevant to our interpretation of overall results is the ca. 3-Myr TL result in unit G1, just above the B-M boundary. This sample (97-2) was intentionally collected from the interior facies. As such, an anomalous age overestimate was expected because the sediment grains were deposited and redeposited by subterranean streams and water flows, precluding any exposure to daylight since they entered the cave systems. This sediment entered the caves probably in the early Pleistocene or before (e.g., Carbonell et al., 1999; Parés and Pérez-González, 1999). Thus, when compared to the TL results from the overlying units G2 and $G 3$, this TL result confirms the geological interpretation of the deposits as consisting of either clearly interior facies (unit G1) or clearly exterior facies (overlying units). 
Table 2

Dose rate, IRSL, and $\pi \mathrm{l}$ data, with cal culated ages for the Atapuer ca samples

\begin{tabular}{|c|c|c|c|c|c|c|c|c|c|c|}
\hline Stratigraphic unit & $\begin{array}{l}\text { Sample }^{2} \\
\text { (ATP) }\end{array}$ & $\begin{array}{l}l .3+5=5 \\
\vdots=c . C 5\end{array}$ & $\begin{array}{l}\mathrm{K}_{2} \mathrm{C} \text { urz̈. } \\
\mathrm{I}=\mathrm{C} .05)^{\prime}\end{array}$ & 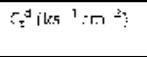 & $c_{\text {tr }}{ }^{3}$ iks $1: n=$ & 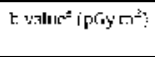 & EAse rate ':iy;ka! & $\begin{array}{l}\text { Prrt.c.3t } \\
\text { r }\end{array}$ & $D_{1}^{r}-\left(a y^{\prime}\right.$ & 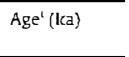 \\
\hline \multicolumn{11}{|l|}{ Surface soils } \\
\hline $0.5-3.0 \mathrm{~cm}$ & $97-1$ & & & & & $0.95 \pm 0.09$ & $3.0 \pm 0.4$ & :33i:53 & $.5 \bar{\Sigma} \pm \therefore .: 3 \operatorname{sil} 12 L_{1}^{2}$ & $0.52 \pm 0.08$ \\
\hline $0.5-3.0 \mathrm{~cm}$ & $98-1$ & & & & & $0.94 \pm 0.11$ & $3.0 \pm 0.4$ & נي: & $2.2 \div \pm 8.21 ;[R \div 2 \varepsilon: 7$ & $0.75 \pm 0.11$ \\
\hline $0.5-3.5 \mathrm{~cm}$ & $98-2$ & & & & & $0.98 \pm 0.08$ & $3.0 \pm 0.4$ & $: 33 i: 53$ & $\therefore, 15 \pm \therefore 23,[R-22 \div: 2$ & $1.49 \pm 0.22$ \\
\hline $0.5-3.0 \mathrm{~cm}$ & $98-3$ & & & & & $1.01 \pm 0.21$ & $3.0 \pm 0.4$ & ננ:יונצ: & נ.j & $0.26 \pm 0.04$ \\
\hline $10 \mathrm{~cm}$ & $97-11$ & & & & & $0.82 \pm 0.07$ & $3.0 \pm 0.4$ & $: 39 i: 53$ & 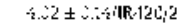 & $134 \pm 0.20$ \\
\hline $40 \mathrm{~cm}$ & $97-12$ & & & & & $0.84 \pm 0.05$ & $3.0 \pm 0.4$ & נتَ: & 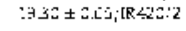 & $6.43 \pm 0.97$ \\
\hline \multicolumn{11}{|l|}{ Galería } \\
\hline $\mathrm{G} 4 / \mathrm{mid}$ & $98-19$ & 0.14 & $\begin{array}{l}0.18 \\
0.11\end{array}$ & $\begin{array}{l}0.1319 \pm 0.0032 \\
0.0917 \pm 0.0026\end{array}$ & 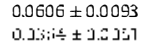 & $138 \pm 0.26$ & $0.606 \pm 0.061$ & $160 / 180$ & $814 \pm 64 /[R 420 / 2$ & $1340 \pm 170^{* *}$ \\
\hline G4/base & $97-14$ & 0.25 & $\begin{array}{l}2.04 \\
1.27^{*}\end{array}$ & $\begin{array}{l}0.660 \pm 0.011 \\
0.600 \pm 0.058\end{array}$ & $\begin{array}{l}0.380 \pm 0.037 \\
0.347 \pm 0.025\end{array}$ & $0.82 \pm 0.26$ & $2.76 \pm 0.27$ & $\begin{array}{l}180 \\
: 5.3 i: 5.3\end{array}$ & 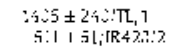 & $\begin{array}{l}510 \pm 100 \\
185 \pm 26^{* *}\end{array}$ \\
\hline \multirow[t]{2}{*}{$\mathrm{G} 3 / \mathrm{top}$} & $98-17$ & 0.18 & $\begin{array}{l}0.44 \\
1.49\end{array}$ & $\begin{array}{l}0.2287 \pm 0.0041 \\
0.4939 \pm 0.0098\end{array}$ & $\begin{array}{l}0.123 \pm 0.013 \\
0.262 \pm 0.034\end{array}$ & $0.9 \pm 0.2$ & $1.460 \pm 0.092$ & $\begin{array}{l}: 5 J \\
160 / 180\end{array}$ & 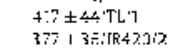 & \\
\hline & & & & & & & \multicolumn{3}{|c|}{ Weighted mean $D_{\mathrm{E}}=393 \pm 28$} & $269 \pm 27$ \\
\hline \multirow[t]{3}{*}{ G3/mid } & $97-24$ & 0.25 & 1.97 & $0.6940 \pm 0.0084$ & $0.381 \pm 0.030$ & $0.81 \pm 0.45$ & $2.62 \pm 0.38$ & 175 & j55 । $>1 . T L_{. ; 1}$ & $224 \pm 42$ \\
\hline & & & $0.93^{*}$ & $0.349 \pm 0.070$ & $0.184 \pm 0.039$ & & & $150 / 170$ & $470 \pm S B^{\prime} \mid R+2 \mathrm{~J} / 2$ & \\
\hline & & & & & & & & \multicolumn{3}{|c|}{ Wrighrest trean uppre $63=256 \pm 23^{*}$} \\
\hline G3/lower & $98-15$ & 0.18 & $\begin{array}{l}0.55 \\
0.69\end{array}$ & $\begin{array}{l}0.3093 \pm 0.0044 \\
0.3307 \pm 0.0062\end{array}$ & $\begin{aligned} 0.6285 & \pm 0.0095 \\
0.177 & \pm 0.020\end{aligned}$ & $1.06 \pm 0.29$ & $1.42 \pm 0.12$ & $\begin{array}{l}175 \\
: 53 i: 72: 28\end{array}$ & 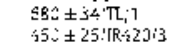 & $480 \pm 48$ \\
\hline \multirow[t]{3}{*}{ G3/base } & $97-19$ & 0.18 & 1.92 & $0.816 \pm 0.011$ & $0.494 \pm 0.041$ & $1.48 \pm 0.45$ & $3.72 \pm 0.42$ & : & $\left.: C 3 \approx \pm 7\left[L_{i} ; I_{L}\right]\right\rceil$ & $439 \pm 66$ \\
\hline & & & $1.18^{*}$ & $0.492 \pm 0.080$ & $0.250 \pm 0.032$ & & & \multirow{2}{*}{\multicolumn{3}{|c|}{ Weighted mean base $63=466 \pm 39^{* *}$}} \\
\hline & & & & & & & & & & \\
\hline \multirow[t]{2}{*}{ G2/mid } & $98-12$ & 0.25 & 230 & $0.851 \pm 0.012$ & $0.364 \pm 0.039$ & $3.03 \pm 0.73$ & $3.04 \pm 0.26$ & 165 & $\because 26 i \pm 15 i_{i} \pi_{i} 1$ & $422 \pm 55^{* *}$ \\
\hline & & & $1.94^{*}$ & $0.576 \pm 0.12$ & $0.252 \pm 0.061$ & & & 175 & 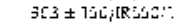 & \\
\hline \multirow[t]{2}{*}{ G2/base } & $97-6$ & 0.20 & 2.27 & $0.805 \pm 0.012$ & $0.430 \pm 0.041$ & $1.19 \pm 0.49$ & $392 \pm 0.42$ & $: 75 i: 8 i$ & $: 37 \pm 370, \pi, 2$ & $503 \pm 95^{* *}$ \\
\hline & & & 1.72 & $0.769 \pm 0.011$ & $0.399 \pm 0.011$ & & & נت:: & 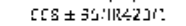 & \\
\hline \multirow[t]{2}{*}{ Above $B-M$} & $97-2$ & 0.22 & 1.71 & $0.817 \pm 0.013$ & $0.480 \pm 0.048$ & $1.0 \pm 0.2^{\mathrm{k}}$ & $3.50 \pm 0.20$ & 180 & 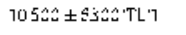 & $3000 \pm 1800^{* *}$ \\
\hline & & 0.19 & $1.79^{*}$ & $0.926 \pm 0.010$ & $0.476 \pm 0.025$ & & & & & \\
\hline \multicolumn{11}{|l|}{ Gran Dolina } \\
\hline TDniwerge & $97-13 a$ & & & & & & $3.0 \pm 0.4$ & 150 & 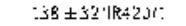 & $46 \pm 7$ \\
\hline \multirow[t]{2}{*}{ TDil wedge } & $97-13 b$ & & & & & & $3.0 \pm 0.4$ & 160 & & $76 \pm 11$ \\
\hline & & & & & & & & \multicolumn{3}{|c|}{ Weightted 1lleall welge $-55 \pm 14^{*}$} \\
\hline \multirow[t]{4}{*}{ TD11/upper } & $97-37$ & 0.15 & 132 & $0.4407 \pm 0.0080$ & $0.271 \pm 0.029$ & $1.22 \pm 0.17$ & $230 \pm 0.16$ & 170 & 35. । 34́:TR.55.: & \\
\hline & & & & & & & & 180 & 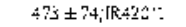 & \\
\hline & & & & & & & & 170 & $45>1<.4 \pi .47 c_{i} 1$ & \\
\hline & & & & & & & \multicolumn{3}{|c|}{ Weighted mean $4420 * D_{E}=484 \pm 35$} & $198 \pm 19^{*}$ \\
\hline TD11/mid & $97-33$ & 0.20 & $\begin{array}{l}1.73 \\
1.56^{*}\end{array}$ & $\begin{array}{l}0.6057 \pm 0.0093 \\
0.5153 \pm 0.0060\end{array}$ & $\begin{array}{l}0311 \pm 0.032 \\
0305 \pm 0.010\end{array}$ & $1.74 \pm 0.75$ & $336 \pm 0.45$ & $160 / 175$ & $810 \pm 100 /[R 420 / 2$ & $240 \pm 44^{* x}$ \\
\hline TD10/upper & $97-45$ & 0.20 & 1.93 & $0.965 \pm 0.014$ & $0.420 \pm 0.046$ & $1.97 \pm 0.85$ & $5.24 \pm 0.79$ & 180 & $1090 \pm 120 / \mathrm{TL} / 1$ & $208 \pm 39$ \\
\hline & & & 2.44 & $1.015 \pm 0.12$ & $0.460 \pm 0.030$ & & & & & \\
\hline TD10/upper & $97-28$ & 0.20 & 233 & $0.901 \pm 0.011$ & $0.378 \pm 0.037$ & $0.72 \pm 0.13$ & $3.39 \pm 0.20$ & $175 / 185$ & $944 \pm 91 / \mathrm{TL} / 2$ & $278 \pm 31$ \\
\hline & & & $1.60^{*}$ & $0.771 \pm 0.010$ & $0.339 \pm 0.020$ & & & & & \\
\hline & & & $0.08^{*}$ & $0.0866 \pm 0.0042$ & $0.034 \pm 0.010$ & & & & & \\
\hline TD10łupper & $98-23$ & 0.20 & 233 & $0.901 \pm 0.011$ & $0.378 \pm 0.037$ & $0.78 \pm 0.30$ & $3.51 \pm 0.31$ & 195 & $670 \pm 240 / 1 \mathrm{~L} / 1$ & $191 \pm 70$ \\
\hline & & & $1.60^{*}$ & $0.771 \pm 0.010$ & $0339 \pm 0.020$ & & & & & \\
\hline & & & $0.08^{*}$ & $0.0866 \pm 0.0042$ & $0.034 \pm 0.010$ & & & & & \\
\hline & & & & & & & & & Sd netar upper TD10 = & $\pm 26^{\circ}$ \\
\hline TD10/mid & $98-20$ & 035 & 2.26 & $0.918 \pm 0.011$ & $0.540 \pm 0.042$ & $0.54 \pm 0.14$ & $2.82 \pm 0.25$ & $175 / 185$ & $1272 \pm 125 / \mathrm{FU2}$ & $430 \pm 59^{k *}$ \\
\hline & & & $1.22^{*}$ & $0.58 \pm 0.25$ & $0.28 \pm 0.13$ & & & 160 & $580 \pm 80 /[R 420 \nmid]$ & \\
\hline & & & & & & & & 165 & $358 \pm 95[R 55012$ & \\
\hline TD9 & $97-53$ & 0.20 & 1.91 & $0.821 \pm 0.12$ & $0.459 \pm 0.043$ & $132 \pm 0.24$ & $3.97 \pm 0.37$ & 190 & $1920 \pm 490 / \pi / 1$ & $480 \pm 130^{* *}$ \\
\hline & & 0.15 & $0.88^{*}$ & $1.18 \pm 0.28$ & $0.154 \pm 0.020$ & & & 190 & $750 \pm 140 / 21200 / 1$ & \\
\hline
\end{tabular}


As discussed above, there have been very few independent numeric ages for these cave deposits. The ESR and U-series results mentioned above are summarized in Fig. 2 (right). The luminescence age estimates are consistent with those results and fill in stratigraphic age gaps. Moreover, the luminescence age estimates suggest the existence of a previously unsuspected timestratigraphic gap within unit G3 in the interval ca. 250-400 ka. Additional, more precise (stratigraphically and analytically) dating is needed to confirm this suggestion.

Nonetheless, these results at this site now suggest that unit G3 and at least the upper part of unit G2 are likely younger than the rich hominin-fossil-bearing deposits in nearby Sima de los Huesos (Fig. 1), recently estimated to be at least $530 \mathrm{ka}$ in age (Bischoff et al., 2007). The imprecise result $(503 \pm 95 \mathrm{ka})$ for the base of unit G2 adds little to this between-site comparison, and the entire unit G2 may be only ca. $450 \mathrm{kyr}$ old (the weighted mean of the two results in Fig. 2, right, is $\mathbf{4 4 2} \pm \mathbf{4 8} \mathrm{ka}$ ). Nevertheless, this new relative chronostratigraphy for the two sites may help in the interpretation of tool development in the middle Pleistocene because Galería is rich in fauna and artifacts.

\section{Age comparisons at Gran Dolina}

The stratigraphically correct locations (Pérez-González et al., 2001) of the combined ESR-U-series age estimates from ungulate teeth (Falguères et al., 1999, 2001) are plotted in Fig. 2 (left). The luminescence ages above unit TD10 appear reasonable. Interestingly, two unpublished U-series age estimates for vein fill in TD11 of mean $240 \pm 25 \mathrm{ka}$ (Bischoff, pers. comm.) are consistent with the luminescence results from TD11.

To provide a clearer graphical comparison of the various results from Gran Dolina, we plot in Fig. 7 the mean ESR-U-series age estimates from Fig. 2 with the main luminescence results from Fig. 2, as well as the individual TL ages from upper TD10. The TL results in the central Fig. 7 may be interpreted in two ways: (1) the TL results from upper TD10 and the oldest ESR-U-series results (in TD6) are inaccurate (too young); or (2) two of the ESR-U-series mean ages are inaccurate (the one at $\sim 16 \mathrm{~m}$ in uppermost TD10, and the one below the Aurora stratum). The second interpretation implies that the luminescence ages from upper TD10 are accurate and that the apparent 250-400-kyr stratigraphic age gap observed at Galería occurs also at Gran Dolina. Apart from the possibility that the TL results from upper TD10 are too young because of unremoved anomalous-fading components (see discussion in online Supplementary material), further studies are required to determine which of these two interpretations for upper TD10 is correct.

The TL ages from units below upper TD10 are consistent with both the ESR-U-series age estimates and the presence of the B-M boundary in upper TD7. This consistency gives us confidence in the TL results. The two oldest TL results (lower unit TD8 and unit TD7) and the ESR-U-series ages from the middle of TD8 are also consistent with the biostratigraphic age-control (mentioned above) in upper unit TD8 that is provided by the last occurrence of remains of the vole $M$. savini. This last-presence datum assigns lower deposits to ages older than ca. $500 \mathrm{ka}$. The data in Figs. 2 (left) and 7 suggest that the ESR-U-series ages (mean $730 \pm 63 \mathrm{ka}$ ) from unit TD6 are underestimations.

In summary, the TL results from the units TD8 and TD9 above the B-M boundary at Gran Dolina support the ESR-U-series results from TD8 and establish clearly that unit TD8 represents a time interval corresponding to the lower-limiting age (ca. $530 \mathrm{ka}$; Bischoff et al., 2007) of the several remarkable hominin fossils in Sima de los Huesos. 


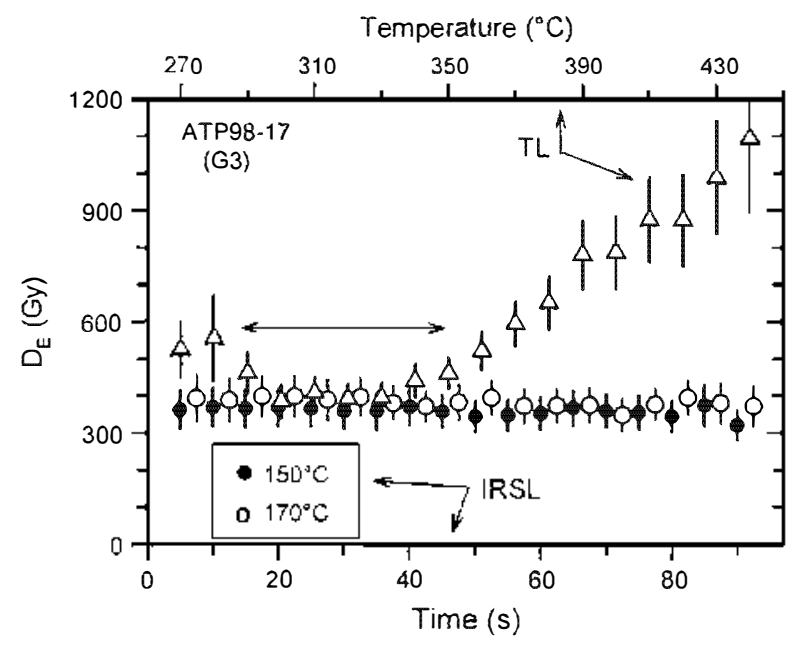

Fig. 4. $D_{E^{-t}}$ plots for IRSL and a $D_{E^{-}}-T$ plot for TL from sample ATP98-17 from unit G3. The horizontal arrow denotes the temperature range used for calculating a mean TL $D_{E}$ value, and thus a TL age for this sample.

\section{Implication of the oldest TL result at Gran Dolina}

The age estimate of ca. 960 ka for sample $97-41$ (Figs. 2 and 7), although imprecise, may be the oldest TL feldspar result in the world that is consistent with stratigraphic and other evidence [in this case, paleomagnetic). Taken at face value, this result implies that the hominin fossils in the TD6 unit at Gran Dolina are probably about 900 kyr old or somewhat older (Fig. 7 ).

From a strictly numerical-dating viewpoint, it is logical to extrapolate the main age-depth trend in Fig. 7 and to consider the implications. Linear excrapolation of the main trend is approximated by line $a$, which is constrained to pass from the intersection of the main trend with the Aurora stratum to the age-depth poinc of $1.8 \mathrm{Ma}$ at $0.9 \mathrm{~m}$. At $0.9 \mathrm{~m}$, a single-sample normal-polarity data point is reported (Parés and Pérez-González, 1999) to be either an excursion or a normal-polarity interval within the longer Matuyama reversal interval. The Olduvai normal-polarity interval occurs at ca. $1.8 \mathrm{Ma}$ (Horng et al., 2002). If the normal-polarity datum at $0.9 \mathrm{~m}$ represents the Jaramillo interval (as preferred by Parés and Pérez-González, 1999), then trend $b$ is more probable.

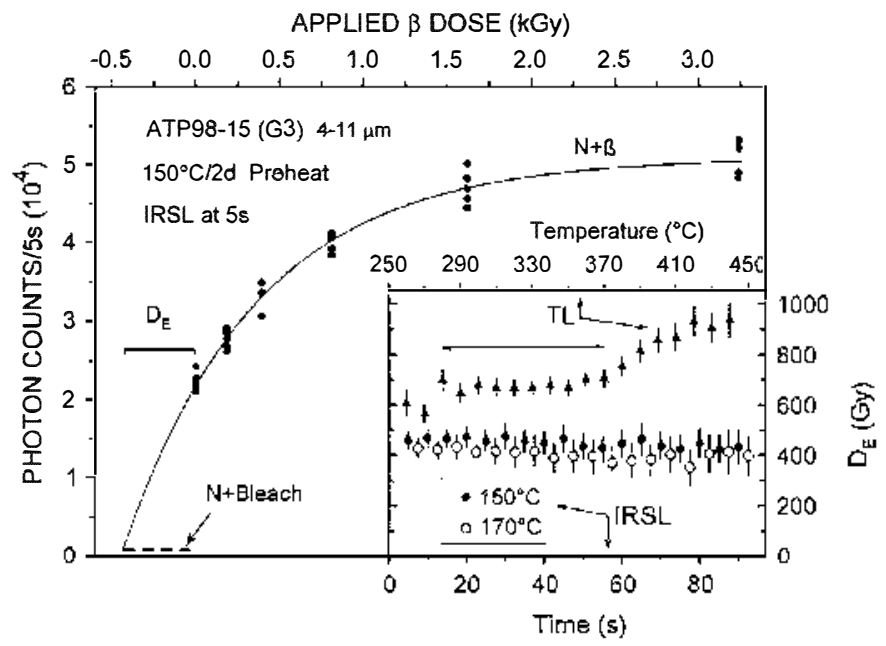

Fig. 5. Total-bleach dose-response $D_{E^{-}}$and $D_{E^{-T}}$ plots for sample ATP98-15 (unit G3). Here, the TL data are fitted to a saturating-exponential (E) regression model.

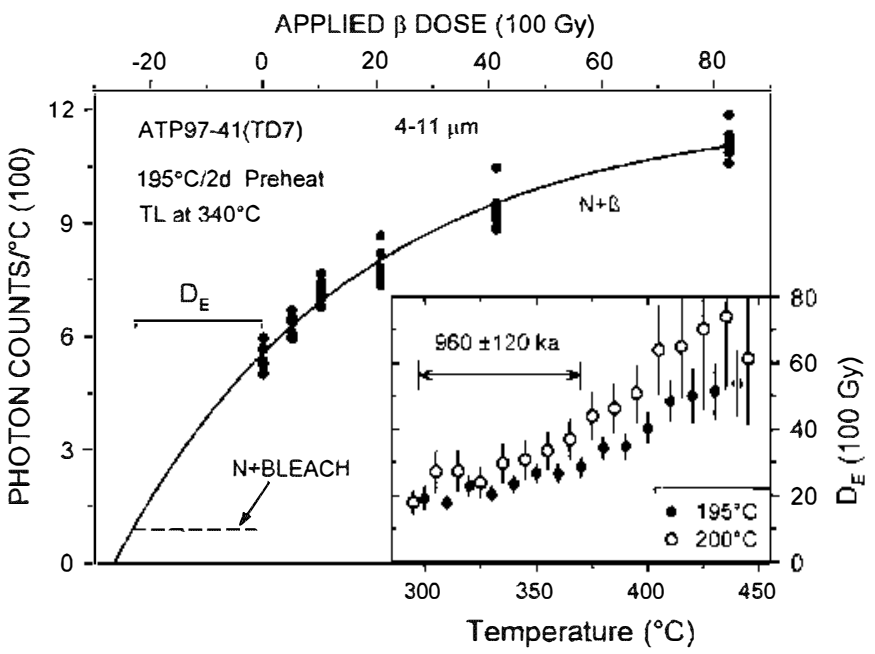

Fig. 6. Total-bleach dose-response and $D_{1:-T}$ plo:s for the oldest luminescence sample at Gran Dolina. Here, eight aliq jo:s wete 'used at each dose point, with an E regtession model.

Srratigraphic age-depch trend $a$ implies that sediments at Gran Dolina are preserved at least since ca. 1.8 Ma. How realistic is this? At the nearby Elefante site (Fig. 1), the greater portion of the $\sim 25 \mathrm{~m}$ of exposed sediments was deposited before $0.8 \mathrm{Ma}$, likely in the interval $0.8-1.8 \mathrm{Ma}$, based on paleomagnetic reversal stratigraphy and biostratigraphic evidence (Parés et al., 2006). In the latter case, the recovery of Mode I (Oldowan) lithic-tool fragments in sedimentary units TE9 to TE13 (numbered bottom to top; Parés et al., 2006) and a hominin premolar and mandible in unit TE9 (Carbonell et al., 2008) clearly establishes that humans were present in this area before at least $1.1 \mathrm{Ma}$. Based on the insectivore assemblage in units TE8 to TE14, Cuenca-Bescós and Rofes (2004) considered this sequence to be older than ca. $1.2 \mathrm{Ma}$, while Rofes and Cuenca-Bescós (2006: 313) deduced that the whole faunal assemblage in this sequence "indicates a warm period that could be correlated with the north European Waalian" period (ca. 1.25-

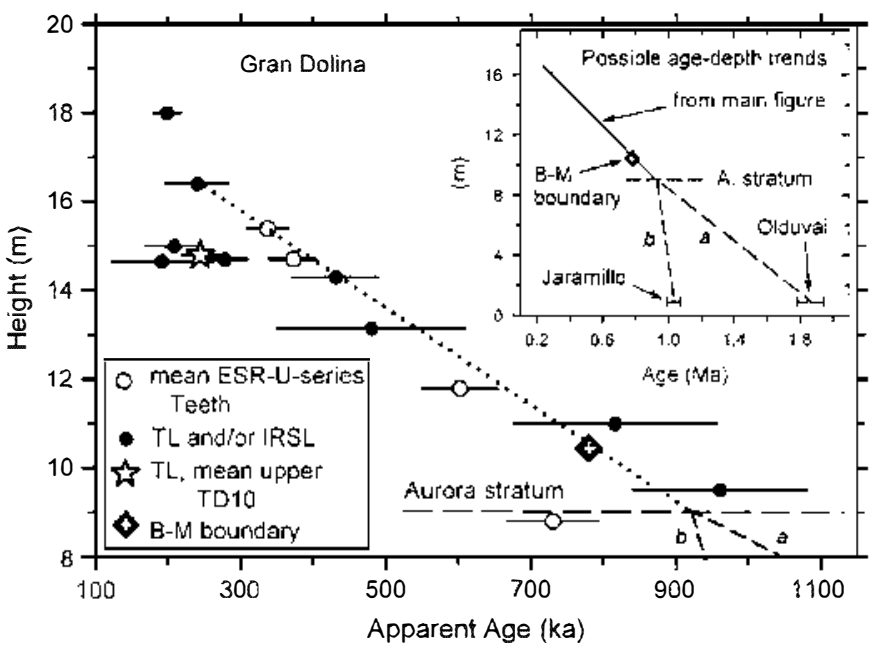

Fig. 7. In the main figure, a plo: of TL and IRSL ages from Table 2 denoted with two asterisks $\left(^{* *}\right.$ ) (see Footnote $\mathrm{i}$ ir. Table 2 ) and mean ESR-U-series ages from ungulate teeth at Gran Dolina, using the stratigraphic locations for the ESR-U-series results from Pérez-González et al. (2001). The hominin fossils recovered here occur in the Aurora stratum. The dotted line is a conjectured age-depth trend. The inset figure shows this trend line, the Aurora stratum, the chronostratigraphic location of the B-M reversal boundary, and two postulated sedimentation-rate trends ( $a$ and $b$ ) discussed in the text. 
$1.50 \mathrm{Ma})$. Another datum relevant to discussion of trend $a$ is the observation (Garcia and Arsuaga, 1999) of remains of the hyaenid Crocuta crocuta in units TD3-TD4 ( $\sim \mathrm{m}$ in Fig. 7, inser) at Gran Dolina. Trend $a$ (Fig. 7) implies that the remains of $C$. crocuta in TD3-TD4 represent a first appearance in western Europe at ca. 1.4$1.5 \mathrm{Ma}$. This is not unreasonable given that Crocuta was already present on the Arabian Peninsula by ca. 1.5 Ma (Garcia and Arsuaga, 1999). Finally, trend $a$ removes the need for an explanation for the apparently sudden change in average sedimentation rate around the level of the B-M boundary that is required by trend $b$.

Set againsc this trend- $a$ excrapolation are the arguments in support of trend $b$. Trend $b$ is consistent with the incerpretation of Parés and Pérez-González (1999) and Pérez-González et al. (2001) that the single-sample paleomagneric datum at $0.9 \mathrm{~m}$ in Gran Dolina represents either the Jaramillo normal-polarity interval (ca. $1.1 \mathrm{Ma}$ ) or the slightly older (ca. $1.18 \mathrm{Ma}$; Horng et al., 2002) Cobb Mountain normal-polarity interval.

Trend $b$ is supported by previous biochronological interpretations, though these necessarily have low time resolution. The biochronological interpretations of carnivores and small mammals, among others (Cuenca-Bescós et al., 1999; García and Arsuaga, 1999, 2001; Antoñanzas and Cuenca-Bescós, 2002; Cuenca-Bescós and García, 2007), indicate that the Gran Dolina strata near and below TD6 (which contains hominin remains) have a faunal assemblage "a bit more advanced than the Jaramills faunas in Vallonnet and Les Valerots (France) or Untermassfeld (Germany)" (G. Cuenca-Bescós, pers. comm.), and thus somewhat younger than Jaramillo age. Moreover, the TD6 and stratigraphically nearby faunal assemblayes appear to be younger than those at the Elefante site, which we stated above to be of probable pre-jaramillo age.

Moreover, trend $b$ is more consistent with indirect geomorphic evidence than is trend $a$. Trend $a$ implies that unit TD1 is of Olduvai age, but this is apparently contradicted by geomorphic evidence. Because TD1 deposits are of vadose origin (above base level), and their elevation ( $\sim 990 \mathrm{~m}$ above sea level) correlates to an elevation just above the $+60-67-m$ (above the present alluvial plain) Pleistocene fluvial terraces of the nearby Arlanzón River (e.g., Parés and Pérez-González, 1999), then trend $a$ implies that these terraces at $+60-67-m$ elevation also must be of Olduvai age. However, BenitoCalvo et al. (2008) interpreted these $+60-67-\mathrm{m}$ terraces as of Brunhes-Matuyama-reversal age ( $\sim 0.8 \mathrm{Ma})$, much younger than the Olduvai. The paleomagnetic-polarity directions from these $+60-67-m$ terraces are reversed, while the next younger (lower, $+50-54 \mathrm{~m}$ ) and older (higher, $+70-78 \mathrm{~m}$ ) terraces contain normalpolarity directions (Benito-Calvo et al., 2008; Other terraces in the region under $+60-67 \mathrm{~m}$ in elevation have a middle Pleistocene age based on the fauna (Sesé et al., 2000) and lithics (Santonja and Pérez-González, 2002) of middle-Pleistocene-age associations. In summary, this indirect geomorphic evidence suggests that level TD1 at Gran Dolina is significantly younger than Olduvai age. Efforts have begun by the Atapuerca research team to date the regional terraces (e.g., by cosmogenic nuclides), and this effort should help to settle the question of which extrapolated age-depth trend is more realistic.

Additional evidence supporing either of trend hypothesis $a$ or $b$ could logically come from more detailed dating studies within the lower units at Gran Dolina. Several of the paleomagnetic samples below the Aurora stratum analyzed by Parés and Pérez-González (1999) were spaced $1.0-1.5 \mathrm{~m}$ apart. Thus, the presence of Jaramillo-age sediments somewhat below TD6 could have been undetected. Improved precision of luminescence dating within TD7 and older (if possible); exterior-facies strata at Gran Dolina also would be useful. Finally, application of cosmogenic-nuclide dacing of exterior-facies cave-sediment quartz grains (e.g., Anthony and Granger, 2007; Carbonell et al., 2008) has promise for these lower strata.

\section{Conclusions}

Luminescence dating is applicable to karstic infill sediments if there is a plausibly eolian origin to inwashed silt grains. With the dose rates measured at Atapuerca, multi-aliquot $\mathrm{TL}$ dating of feldspar-bearing fine silt is presently more reliable for samples older thanca. 200 ka than is multi-aliquot IRSL dating. Furthermore, comparisons of our TL results with stratigraphic constraints (viz., the B-M geomagnetic-reversal boundary at $780 \mathrm{ka}$; independent stratigraphic microfossil evidence at Gran Dolina, and ESR-U-series daring suggest that our preferred $\mathrm{Tl}$.ages are generally accurate, and that reliable TL dates up to ca. 1 Ma can be obtained from fine-silt feldspars in some areas. Because of lack of access to the appropriate luminescence-reading instrument systems during this project, we have not investigated the usefulness of single-aliquot quartz grains in dating samples at Atapuerca, but we are skeptical of its potential for most of the strata (those older than ca. $200 \mathrm{ka}$ ). The sediments at Atapuerca have dose rates 5-7 times higher than those for the quartz-rich sediments analyzed by Rhodes et al. (2006) and Prideaux et al. (2007a), who reported quartz ages up to 500-900 ka.

The TL age-depth seriation at Gran Dolina suggests that, as at Galería, the sediments and associated remains representing the time interval $250-400 \mathrm{ka}$ are missing, but at Gran Dolina, the critical luminescence results in upper TD10 could be too young, and this apparent gap may be only an artifact there.

The TL dating results from Galería suggest that faunal and lithic remains in stratigraphic units lower G3 and G2 at ca. $450 \mathrm{ka}$ are younger than the remarkable hominin remains from the nearby Sima de los Huesos site ( $>530 \mathrm{ka}$ ). Our oldest TL result ( $960 \pm$ $120 \mathrm{ka}$ ) for unit TD7 at Gran Dolina implies that the probable age of the hominin remains in the underlying TD6 horizon lies in the age range 900-950 ka. Since much of the TD6 unit represents an incerglacial paleoclimatic stage (e.g. Sánchez-Marco, 1999), "perhaps very similar to that of the modern Cantabrian habitat" (Cuenca-Bescós et al., 2005: 285), our results (Fig. 7) imply an association of the hominin remains with Marine Isotope Stage (MIS) 25, a relatively warm and humid interglacial period. Previously, on the basis of an overinterpretation of the available ESR-Useries age estimates (e.g., Fig. 2, left, and Fig. 7) and biostratigraphic data, Cuenca-Bescós et al. (2005) suggested a correlation of the Aurora stratum with MIS 21.

The present results have important implications for reconstructing the history of human evolution in Europe. These results suggest an increase in the rempural gap between the TD6 hominins (1) Ho antecessor) and the middle Pleistocene hominins (Homo heidelbergensis). Cuenca-Bescós et al. (2005: 285) concluded that the presence of $H$. antecessor in TD6 "may reflect the ecological preferences of this species to the warmer and more equable conditions of southern Europe" whereas "the general opening of the landscape ... characterized in Atapuerca by the small-mammal association of TD10, could have favored the dispersal" of later hominins (e.g., $H$. heidelbergensis' across Europe. Our results also suggest the need for future studies of the possible phylogenetic relationship between these species (Bermúdez de Castro et al., 1997, 2003; Martinón-Torres et al., 2007) and of the possitsle evolutionary events that occurred in Europe prior to $400 \mathrm{ka}$. Furthermore, the possible temporal coincidence between the TD6 hominins and the Ceprano calvaria (Ascenzi et al., 1996) offers another interesting debate about their possible relationship, especially if the species Homo cepranensis (Mallegni et al., 2003) is also accepted.

\section{Acknowledgements}

The luminescence dating was supported by grant BNS-9805174 to GWB from the U.S. National Science Foundation (NSF). GWB especially thanks James Bischoff for early and continued 
encouragements, Spanisly colleagues for some early travel support, and NSF and the Desert Research Institute for continued support of the infrastructure of the luminescence dating laboracory. This study was also sponsored by the Junta de Castilla y León, Fundación Atapuerca, and Ministerio de Educación y Ciencia Grant DGI CGL200613532-C03. Special thanks are also due Sarah Roeske and Joe Cain of the Iniversity of California, Davis, for conducting SFM-FDX analyses. We also thank two anonymous reviewers for their calmly pointed remarks that motivated a serious reorganization of our text.

\section{Appendix A. Supplementary data}

Supplementary material associated with this article can be found in the online version, at doi:10.1016/j.jhevol.2008.02.012.

\section{References}

Abeyratne, M., Spooner, N.A., Grïn, R, Head, J., 1997. Multidating studies of Batadomba Cave, Sri Lanka. Quatern. Sci. Rev. 16, 243-255.

Adamiec, G., Aitken, M.J., 1998. Dose-rate conversion factors: update. Ancient TL 16, $37-50$.

Aguirre, E., 1994. Dating the Ibeas humans: attempts and question marks. Cour. Forsch.-Inst Senckenberg 171, 197-204.

Aguirre, E., Carbonell, E., 2001. Early human expansions into Eurasia: the Atapuerca evidence. Quatern. Int 75, 11 18

Aguirre, E., Arsuaga, J.L., Bermúdez de Castro, J.M., Carbonell, E., Ceballos, M., Díez, C., Frıamotade, J., Fernández-Jalvo, Y., Gisl, E., Gracia, A., Martín-Nájera, A., Martínez, I., Morales, J., Ortega, A.I., Rosas, A., Sánchez, A., Sánchez, B., Sesé, C., Soto, E., Torres, T.J., 1990. The Atapuerca sites and the Ibeas hominids. Hum Evol. 5, 55-73.

Aitken, M.J., 1985. Thermoluminescence Daling. Academic Press, New York.

Aitken, M.J., 1998. An Introduction to Cptical Dating: The Dating of Quaternary Sediments by the Use of Photon-Stimulated Lurninescence. Oxford University Press, Oxford.

Ả leixandre, T., Pérez-González, A., 1999. Faciesmineralógicas de las arenas de los rellenos kársticos de la Sierra de Atapuerca 'Butgosj. In: Andreo, B., Cirrasio, F., IJurír, I.]. (Eds.), Contribución del Estudio Científicc de las Cavidades Kársticas al Conocimiento Geológico, Patronato de la Cueva de Nerja, Nerja, Málaga, pp. 731 747.

Ambrose, S.H., 2001. Paleolithic technology and human evolution. Science $291_{1}$ $1748-1753$.

Anthony, D.M., Granger, D.E., 2007. A new chronology of Appalachian erosional surfaces determined by cosmogenic nuclides in cave sediments. Earth Surf. Proc. Landforms 32, 874-887.

Antoñanzas, R.L., Cuenca-Bescós, G., 2002. The Gran Dolina site (lower to middle Pleistocene, Atapuerca, Burgos, Spain): new palaeoenvironmental data based on the distribution of small mammals. Palaeogeogr. Palaeoclimatol. Palaeoecol. $186,311-334$

Arsuaga, J.L., 2003. Requiem for a heavyweight Nat Hist 111(10), 43-48.

Arsuaga, J.L., Martínez, I., Gracia, A., C.arsererl. J.M., Carbonell, E., 1993. Three new human skulls from the Sima de los Huesos site in Sierra de Atapuerca, Spain. Nature 362, 534-537.

Arsuaga, J.L., Bermúdez de Castro, J.M., Carbonell, E., 1997a. Preface. J. Hum. Evol. 33, $105-108$.

Arsuaga, J.L., Martínez, I., Gracia, A., Carretero, J.M., Lorenzo, C., García, N., Ortega, A.I., 1997 b. Sima de los Huesos (Sierra de Atapuerca, Spain): the site. J. Hum Evol. 33, 109-127.

Atśaga, J.L. Lorenzo, C., Carrctcto, J.M., Gracia, A., Martínez, I., García, N., Bermúdez de Castro, J.M., Carbonell, E., 1999a. A complete human pelvis from the middle Pleis tocene of Spain. Nature 399, 255-258.

Arstingi, J.I., Martínez, I., Lorenzo, C., Gracia, A., Muñoz, A., Alonso, O., Gallego, J., $1999 \mathrm{~b}$. The human cranial remains from Gran Dolina lower Pleistocene site (Sierra de Atajulesca, Spain). J. Hum. Evol. 37, 431-457.

Ássliaga, J.L., Gracia, A., Lorenzo, C., Martínez, I., Pérez, P.J., 1999c. Resto cranial hunamo de Galería/Cueva de los Zarpazos (Sierra de Atapuerca, Burgos). Moemorias. Arqueología en Castilla y León 7, 233-235.

Ascenzi, A., Biddittu, I., Cassoli, P.F., Segre, A.G., Segre Naldini, E., 1996. A calvarium of late Homo erectus from Ceprano, Italy. J. Hum. Evol. 31, 409-423.

Balter, M., 2001. In search of the first Elropcans. Science 291, 1722-1725.

Benito-Calvo, A., Pérez-González, A., Parés, J.M., 2008. Quantitative reconstruction of late Cenozoic landscapes: a case study in the Sierra de Atapuerca (Burgos, Spain). Earth Surf. Proc. Landforms, 33, 196-208.

Berger, G.W., 1984. Thermoluminescence dating studies of glacial silts from Ontario. C.an. J. Earth Sci. 21, 1393-1399.

Berger, G.W., 1988. Dating Quaternary events by luminescence. In: Easterbrook, D.J. 'E.t.: Dating Q1uaternary Sediments. Geol. Soc. Am. Spec. Pir. 227, 13-50.

Berger, G.W., 1994. Thermoluminescence dating of sediments older than $-100 \mathrm{ka}$. Quatern. Sci. Rev. 13, 445-455.

Berger, G.W., 1995. Progress in luminescence dating methods for Quaternary sediments. In: Rutter, N.W., Catto, N. (Eds.), Dating Methods for Quaternary Deposits. Geol. Assoc. Can. GEOtext 2, 81-103. In: Storer, J.E. (1.d.i, Canadian Quaternary Assoriation Metings, 2001: Program and Abstracts. Ycikon Heritage Branch Occasional Papers in Earth Science, vol. 1. Government of the Yukon, p. 26.

Berger, G.W., 2003. Luminescence chronology of late Pleistucene loess-paleosol and tephra sequences near Fairbanks, Mlaska. Quatcrn. Res. 60, 70-83.

Berger, G.W., Pérez-González, A., 2000. Some optical dating results from karstic cave sediments at Ataplerca, Spain. J. Hum. Evol. 38, A6-A7.

Berger, G.W., Péwé, T.L., 2001. Last-Interglacial age of the Eva Forest Bed, central Alaska, from thermoluminescence dating of bracketng loess. Quatern. Sci. Rev. $20,485-498$

Berger, G.W., Pillans, B.J., Palmer, A.S., 1992. Dating loess up to $800 \mathrm{ka}$ by thermoluminescence. Geology 20, 403-406.

Berger, G.W., Murray, A.S., Havholm, K.G., 2003. Photonic dating of Holocene hack larsyer coastal dunes, northern North Carolina, USA. Quatern. Sci. Rev. 22, 1043-1050.

Berger, G.W., Pérez-González, A., Carbonell, E., Arsuaga, J.L., Bermúdez de Castro, J. M. 2005. Luminescence chronology for cave sediments at the Atapuerca paleo-anthropological site, Spain. In: Paleoanthropology Society Annual Mecting Abstracts, Milwaukee, Wisconsin, p. 4.

Bermúdez de Castro, J.M., Arsuaga, J.L., Carbonell, E., Rosas, A., Martínez, I. Mosglerd, M., 1997. A hominid from the lower Pleistocene of Atapuerca Spain: possible ancestor to Neandertals and modern humans. Science 276 1.397 .1 .395

Bermúdez de Castro, J.M., Rosas, A., Nicolás, M.E., 1999. Dental remains from

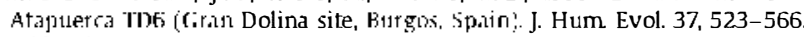

Bermúdez de Castro, J.M., Martinón-Torres, .M., Sarmientc, S., Lozano, M., 2003. Gran Dolina-TD6 versus Sima de los Huesos dental sample from Ataperca: evidence of discontinuity in the European Pleistocene populations? J. Archaecl. Sci. 30, 1421-1428.

Bermúdez de Castro, J.M., Martinón-Torres, M., Carbonell, E., Sarmiento, S., Rosas, A., vander Made, J., Lozano, M., 2004. The Atapuerca sites and their contribution to the knowledge of human evolution in Europe. Evol. Anthropol. 13, 25-41.

Bischoff, J.L., Shamip, D.D., Aramburu, A., Arsuaga, J.L., Carbonell, E., Bermúdez de Castro, J.M., 20013. The Sima de los Huesos hominids date to heyond :lith equilizrilir and perhaps to $400-500 \mathrm{kyr}$ : new radiometric dates. J. Archaeol. Sit. 30, 275-280

Bischoff, J.L., Williams, RW., Rosenbauer, R.J., Aramburu, A., Arsuaga, J.L., García, N., Cuenca-Bescós, G., 2007. High resolistion U-series dates from the Sima de los Huesos hominids yields $600_{-\epsilon \in \mathrm{K}}^{\circ} \mathrm{krs}$ : implications for the evolution of the early Neanderthal lineagc. J. Archacol. Sci. 34, 763-770.

Bøtter-Jensen, L. Mckever, S.W.S., Wintle, A.G., 2003. Optically Stimulated Luminescence Dosimetry. Elsevier, New York.

Cann, R., 2001. Genetic clues to dispersal in human populations: retracing the past from the present Science 291, 17 $\div 2-1748$.

Carbonell, E., Rodriguez, X.P., 2006. The first human settlement of Mediterranean ELrope. C. R. Palevol. 5, 291-298.

Carlsonell, E., Bermúdez de Castro, J.M., Arsuag., J.L., Díez, J.C.., Rosas, A., CuencaBescós, G., Sala, R. Mosquera, M., Rodríguez, X.P., 1995. Lower Pleistocene hominids and artifacts from Ataputerca T1)6 (Spain). Science 269, 826-830.

Carbonell, E., Esteban, M., Nájera, A..Y., Mosquera, M., Rodríguez, X.P., Ollé, A., Sala, R., Vergès, l.M., Bermúdez de Castro, J.M., Ortega, A.I., 1999. The Pleis tocene site of Gran Dolina, Sierra de Atapuerca, Spain: a histery of the archaeological investigations. J. Hum. Evol. 37, 313-324.

Carbon ell, E., Bermudez de Castro, J.M., Pares, J.M., Perez-Gonzalez, A., CuencaBescos, G., Olle, A., Mosquera, M., Huguet, R, van der Made, J., Rosas, A., Sala, R. Vallverdu, J., Garcia, N., Granger, D.E., Martinon-Torres, M., Rodriguez, X.P., Stock, G.M., Verges, J.M., Allue, E., Burjachs, F., Caceres, I., Canals, A., Benito, A. Diez, C., Lozano, M., Mateos, M., Navazo, M., Rodriguez, J., Rosell, J., Arsuaga, J.L, 2008. The first hominin of Europe. Nature 452, 465-470.

Cuenca-Bescós, G., García, N., 2.00\%. Distrilsutions of the early and middle Pleistocene mammals of the Atapuesca cave localities (Spain, South-western Europe). Cour. Forsch.-Inst Sencken'zerg 259, 99-110.

Cuenca-Bescós, G., Rofes, J., 2004. Insectivores (Mammalia), paleoclimate and palcocnvironment from the lower levels of Trinchera Elefante (Atapuerca, lower Pleis tocene). In: Baquedano, E., Rubio, J.S. (Eds.), Miscelánea en Homenaje a Emiliano Agtirre, Volumen II: Paleontología. Zona Arqueológica 4, 151-156 ¿Museu Arquelógico Regional, Alcalá de Henares).

Clicnca-Bescós, G. LaPlana, C., Canudo, J.I., 1999. Biochronological implications of the Arvicolitas (Rodentia, Mammalia) from the lower Plescrocene hominidJearing level of Trinchera Dolina 6 (TD6, Atapuerca, Spain). J. Hum. Evol. 37, $3.33 \% 3$

Cuenca-Bescós, G., Rcfes, J., Garcia-Pimienta, J., 2005. Environmental change across the early-middle Pleistocene transition: small mammalian evidence from the Trinchera Dolina cave, Atapuerca, Spain. In: Head, M.J., Gibbard, P.L. (Eds.i. Early-Middle Pleistocene Transitions: The Land-Ocean Evidence. Gcologica Socjety of London, London, pp. 277-286.

Clilotta, E., Sugden, A., Hanson, B., 2001. Humans on the move. Science 291, 1721.

Delson, E., I997. One skull does not a species make. Nature 389, 445-446.

Dennell, R., 2003. Dispersal and colonisation, long and short chronologies: how continuous is the early Pleistocene record for hominids outside East Africa? J Hum. Evol. 45, 421-440.

Dennell, R., Roebroeks, W., 2005. An Asian perspective on early human dispersal from Africa. Nature 438, 1099-1104.

Dickin, A.P., 1997. Radiogenic Isotope Geology. Cambridge University Press, Cambridge. 
Falguères, C., Bahain, J.-J., Yokoyama, Y., Arsuaga, J.L., Bermúdez de Castro, J.M., Carbonell, E., Bischoff, J.L, Dolo, J.-M., 1999. Earliest humans in Europe: the age of the TD6 Gran Dolina, Atapuerca, Spain. J. Hum. Evol. 37, 343-352.

Falguères, C., Bahain, J.-J., Yokoyama, Y., Bischoff, J.L., Arsuaga, J.L, Bermúdez de Castro, J.M., Carbonell, E., Dolo, J.-M., 2001. Datation par RPE et U-Th des sites Pléistocènes d'Atapuerca: Sima de los Huesos. Trinchera Dolina et Trinchera Galería. Bilan Géochronologique. L'Anthropologie 105, 71-81.

Feathers, J.K., 1997. Luminescence dating of sediment samples from White Paintings Rockshelter, Botswana. Quatern. Sci. Rev. 16, 321-332.

Garcia, N., Arsuaga, J.L. 1999. Carnivores from the early Pleistocene hominid bearing Trinchera Dolina 6 (Sierra de Atapuerca, Spain). J. Hum. Evol. 37, 415430.

García, N., Arsuaga, J.L., 2001. Les carnivores (Mammalia) des sites du Pléistocène ancien et moyen d'Atapuerca (Espagne). L'Anthropologie 105, 83-93.

Gibbons, A., 2001a. The riddle of coexistence. Science 291, 1725-1729.

Gibbons, A., 2001b. The peopling of the Pacific. Science 291, 1735-1737.

Gosse, J.C., Phillips, F.M., 2001. Terrestrial in situ cosmogenic nuclides: theory and application Quatern. Sci. Rev. 20, 1475-1560.

Hagen, E, Kelley, S.P., Dypvik, H., Nilsen, O., Kjølhamar, B., 2001. Direct dating of authigenic K-feldspar overgrowths from the Kilombero Rift of Tanzania. J. Geol. Soc. 158, 801-807.

Horng, C.-S., Lee, M.-Y., Palike, H., Wei, K.-Y., Liang, W.-T., Iizuka, Y., Torii, M., 2002. Astronomically calibrated ages for geomagnetic reversals within the Matuyama Chron. Earth Planets Space 54, 679-690.

Huntley, D.J., Wintle, A.G., 1981. The use of alpha scintillation counting for measuring Th-230 and Pa-231 contents of ocean sediments. Can J. Earth Sci. 18 419-432.

Huntley, D.J., Berger, G.W., Bowman, S.G.E., 1988. Thermoluminescence responses to alpha and beta irradiations, and age determination when the high dose response is non-linear. Radiat. Eff. 105, 279-284

Jacobs, Z., Duller, G.A.T., Wintle, A.G., 2003a. Optical dating of dune sand from Blombos Cave, South Africa: I-multiple grain data. J. Hum Evol. 44, 599 612

Jacobs, Z., Duller, G.A.T. Wintle, A.G., 2003b. Optical dating of dune sand from Blombos Cave, South Africa: II-single grain data. J. Hum. Evol. 44, 613-625.

Jenny, H., 1980. The Soil Resource: Origin and Behavior. Springer-Verlag, New York

Krbetschek, M.R, Götze, J., Dietrich, A., Trautmann, T., 1997. Spectral information from minerals relevant for luminescence dating. Radiat. Meas. 27, 695-748.

Ku, T.-L, 2000. Uranium-series methods. In: Noller, J.S., Sowers, J.M., Lettis, W.R (Eds.), Quaternary Geochronology: Methods and Applications. AGU Reference Shelf, 4. Washington, DC, pp. 101-114.

Kunzig, R, 1997. Atapuerca: the face of an ancestral child. Discover 18(12), 88-101.

Laplana, C., Cuenca-Bescós, G., 1997. Los arvicólidos (Arvicolidae, Rodentia) del limite Pleistoceno Inferior-Medio en el relleno cárstico Trinchera Dolina (Sierra de Atapuerca, Burgos, Espana). XIII Jornadas de Paleontología, 192-195.

wo, S., Ku, T.-L, Roback, R, Murrell, M., McLing, T.L, 2000. In-situ radionuclide transport and preferential groundwater flows at INEEL (Idaho): decay-series disequilibrium studies. Geochim Cosmochim. Acta 64, 867-881.

Mallegni, F., Carnieri, E., Bisconti, M., Tartarelli, G., Ricci, S., Biddittu, I., Segre, A.G. 2003. Homo cepranensis sp. nov. and the evolution of African-European middle Pleistocene hominids. C. R. Palevol. 2, 153-159.

Manzi, G., 2004. Human evolution at the Matuyama-Brunhes boundary. Evol. Anthropol. 13, 11-24.

Marshall, E., 2001a. Pre-Clovis sites fight for acceptance. Science 291, 1730-1732.

Marshall, E., 2001 b. Clovis first. Science 291, 1732.

Martini, I.P., Chesworth,W., 1992. Weathering, Soils and Paleosols. Elsevier, New York.

Martinón-Torres, M., Bermúdez de Castro, J.M., Gómez-Robles, A., Arsuaga, J.L. Carbonell, E., Lordkipanidze, D., Manzi, G., Margvelashvili, A., 2007. Dental evidence on the hominin dispersals during the Pleis tocene. Proc. Natl. Acad. Sci. U.S.A. $104,13279-13282$

McDougall, I., Harrison, T.M., 1999. Geochronology and Thermochronology by the ${ }^{40} \mathrm{Ar}-{ }^{39} \mathrm{Ar}$ Method. Oxford University Press, New York.

Morwood, M.J., Soe jono, R.P., Roberts, R.G., Sutikna, T., Turney, C.S.M., Westaway, K E., Rink, W.J., Zhao, J.-x., van den Bergh, G.D., Due, R.A., Hobbs, D.R, Moore, M.W., Bird, M.I., Fifield, L.K., 2004. Archaeology and age of a new hominin from Flores in eastern Indonesia. Nature 431, 1087-1091.

Murray, A.S., Olley, J.M., 2002. Precision and accuracy in the optically stimulated luminescence dating of sedimentary quartz: a status review. Geochronometria 21, 1-16.

Ollerhead, J., Huntley, D.J., Berger, G.W., 1994. Luminescence dating of the Buctouche Spit, New Brunswick. Can. J. Earth Sci. 31, 523-531.

Olley, J.M., Murray, A., Roberts, R, 1996. The effects of disequilibria in the uranium and thorium decay chains on burial dose rates in fluvial sediments. Quatern Sci. Rev. 15, 751-760.

Olley, J.M., Roberts, R.G., Murray, A.S., 1997. Disequilibria in the uranium decay series in sedimentary deposits at Allen's Cave, Nullarbor Plain Australia: implications for dose rate determinations. Radiat. Meas. 27, 433-443.

Parfitt, S.A., Barendregt, RW., Breda, M., Candy, I., Collins, M.J., Coope, G.R. Durbidge, P., Field, M.H., Lee, J.R., Lister, A.M., Mutch, R., Penkman, K.E.H. Preece, R.C., Rose, J., Stringer, C.B., Symmons, R, Whittaker, J.E., Wymer, J.J.,
Stuart, A.J., 2005. The earliest record of human activity in northern Europe. Nature 438, 1008-1012.

Parés, J., Pérez-González, A., 1995. Paleomagnetic age for hominid fossils at Atapuerca archaeological site, Spain. Science 269, 830-832.

Parés, J., Pérez-González, A., 1999. Magnetochronology and stratigraphy at Gran Dolina section, Atapuerca (Burgos, Spain). J. Hum Evol. 37, 325-342.

Parés, J., Pérez-González, A., Rosas, A., Benito, A., Bermúdez de Castro, J.M., Carbonell, E., Huguet, R., 2006. Matuyama age lithic tools from the Sima del Elefante site, Atapuerca (northern Spain). J. Hum. Evol. 50, 163-169.

Pennisi, E., 2001. Tracking the sexes by their genes. Science 291, 1733-1734.

Prescott, J.R., Hutton, J.T., 1988. Cosmic ray and gamma ray dosimetry for TL and ESR. Nucl. Tracks Radiat Meas. 14, 223-227.

Prescott, J.R. Huntley, D.J., Hutton, J.T., 1993. Estimation of equivalent dose in thermoluminescence dating - the Australian slide method. Ancient TL 11, 1-5.

Prideaux, G.J., Roberts, R.G., Megirian, D., Westaway, K.E., Hellstrom, J.C., Olley, J.M. 2007a. Mammalian responses to Pleistocene climate change in southeastern Australia. Geology 35, 33-36.

Prideaux, G.J., Long, J.A., Ayliffe, L.K., Hellstrom, J.C., Pillans, B., Boles, W.E. Hutchinson, M.N., Roberts, R.G., Cupper, M.L., Arnold, LJ., Devine, P.D., Warburton, N.M., 2007 b. An arid-adapted middle Pleistocene vertebrate fauna from south-central Australia. Nature 445, 422-425.

Pérez-González, A., Aleixandre, T., Pinilla, A., Gallardo, J., Benayas, J., Martínez, M.J., Ortega, A.I., 1995. An approach to the galeria stratigraphy in the Sierra de Atapuerca trench (Burgos). In: Bermúdez de Castro, J.M., Arsuaga, J.L. Carbonell, E. (Eds.), Simposium Evolución Humana en Europa y los yacimentos de la Sierra de Atapuerca, vol. 1, pp. 99-122 (Castillo de la Mota, Medina del Campo, Valladolid).

Pérez-González, A., Parés, J.M., Gallardo, J., Aleixandre, T., Pinilla, A., 1999. Geología y estratigrafía del relleno de Galería de la Sierra de Atapuerca (Burgos). In: Carbonell, E., González, A.R, Fernández-Lomana, J.C.D. (Eds.), Atapuerca: Ocupaciones Humanas y Paleoecología del Yacimiento de Galería. Arqueología en Castilla y León 7, 31-42.

Pérez-González, A., Parés, J.M., Carbonell, E., Aleixandre, T., Ortega, A.I., Benito, A., Merino, M.Á.M., 2001. Géologie de la Sierra de Atapuerca et stratigraphie des remplissages karstiques de Galería et Dolina (Burgos, Espagne). L'Anthropologie $105,27-43$.

Roebroeks, W., 2005. Life on the Costa del Cromer. Nature 438, 921-922.

Rhodes, EJ., Singarayer, J.S., Raynal, J.-P., Westaway, KE., Sbihi-Alaoui, F.Z., 2006. New age estimates for the Palaeolithic assemblages and Pleistocene succession of Casablanca, Morocco. Quatern Sci. Rev. 25, 2569-2585.

Rink, W.J., 1997. Electron spin resonance (ESR) dating and ESR applications in Quaternary science and archaeometry. Radiat Meas. 27, 975-1025.

Roberts, R.G., Galbraith, R., Olley, J., Yoshida, H., Laslett, G., 1999. Optical dating of single and multiple grains of quartz from Jinmium Rock Shelter, northern Australia. Part II: Results and implications. Archaeometry 41, 365-395.

Rofes, J., Cuenca-Bescós, G., 2006. First evidence of the Soricidae (Mammalia) Asoriculus Gibbergodon (Petényi, 1864) in the Pleistocene of north Iberia. Riv. Ital. Paleontol. Stratigr. 112, 301-315.

Rosas, A., Pérez-González, A., Carbonell, E., van der Made, J., Allué, E., García, N., Martínez-Pérez, R, Rodríguez, J., Sala, R, Saladie, P., Simón, G., MartínezMaza, C., Bastir, M., Sánchez, A., Parés, J.M., 2004. Initial approach to site formation and paleoecology of the Sima del Elefante: a Pleis tocene karst locality at Atapuerca hill. Zona Arqueologica 4, 135-155.

Santonja, M., Pérez-González, A., 2002. El Paleolítico inferior en el interior de la Península Ibérica: Un punto de vis ta desde la geoarqueología. Zephyrus 53-54, 27-77.

Scott, G.R., Gibert, L., Gibert, J., 2007. Magnetostratigraphy of the Orce region (Baza Basin), SE Spain: new chronologies for early Pleistocene faunas and hominid occupation sites. Quatern. Sci. Rev. 26, 415-435.

Sesé, C., Soto, E., Pérez-González, A., 2000. Mamíferos de las terrazas del valle del Tajo: Primeras notas de micromamíferos del Pleistoceno en Toledo (España central). Geogaceta 28, 137-140.

Smith, M.A., Prescott, J.R., Head, M. J., 1997. Comparison of ${ }^{14} \mathrm{C}$ and luminescence chronologies at Puritjarra rock shelter, central Australia. Quatern. Sci. Rev. 16, 299-320.

Stumpf, M.P.H., Goldstein, D.B., 2001. Genealogical and evolutionary inference with the human Y chromosome. Science 291, 1738-1742.

Sánchez-Marco, A., 1999. Implications of the avian fauna for paleoecology in the early Pleistocene of the Iberian Peninsula. J. Hum. Evol. 37, 375-388.

Tattersall, I., 1997. Out of Africa again... and again? Sci. Am. 276, 46-53.

Topping, J., 1962. Errors of Observation and Their Treatment Chapman and Hall, London.

Turney, C.S.M., Fifield, LK., Roberts, R.G., Smith, M., Dortch, C.E., Grün, R. Lawson, E. Ayliffe, L.K., Miller, G.H., Dortch, J., Cresswell, R.G., 2001. Early human occupation at Devil's Lair, southwestern Australia 50,000 years ago. Quatern. Res. 55, 3-13.

Verosub, K.L, 2000. Paleomagnetic dating. In: Noller, J.S., Sowers, J.M., Lettis, W.R. (Eds.), Quaternary Geochronology: Methods and Applications. AGU Reference Shelf 4, Washington, DC, pp. 339-356.

Wintle, A.G., 1982. Thermoluminescence properties of fine grain minerals in loess. Soil Sci. 134, 164-170. 